NBER WORKING PAPER SERIES

\title{
INVESTMENT AND THE COST OF CAPITAL: NEW EVIDENCE FROM THE CORPORATE BOND MARKET
}

\author{
Simon Gilchrist \\ Egon Zakrajsek \\ Working Paper 13174 \\ http://www.nber.org/papers/w13174
NATIONAL BUREAU OF ECONOMIC RESEARCH
1050 Massachusetts Avenue
Cambridge, MA 02138 \\ June 2007
}

We appreciate helpful comments and suggestions from Eileen Mauskopf, Stacey Tevlin, Jonathan Wright, and seminar participants at the Federal Reserve Board, the European Central Bank, the Bank of Canada, the Federal Reserve Bank of San Francisco, the Bank of Japan and the University of Tokyo. Jason Grimm and Isaac Laughlin provided superb research assistance. Simon Gilchrist thanks the National Science Foundation for financial support. The views expressed in this paper are solely the responsibility of the authors and should not be interpreted as reflecting the views of the Board of Governors of the Federal Reserve System, or those of anyone else associated with the Federal Reserve System, or the views of the National Bureau of Economic Research.

(C) 2007 by Simon Gilchrist and Egon Zakrajsek. All rights reserved. Short sections of text, not to exceed two paragraphs, may be quoted without explicit permission provided that full credit, including $\odot$ notice, is given to the source. 
Investment and the Cost of Capital: New Evidence from the Corporate Bond Market

Simon Gilchrist and Egon Zakrajsek

NBER Working Paper No. 13174

June 2007

JEL No. E22,E44,E62

\begin{abstract}
$\underline{\text { ABSTRACT }}$
We study the effect of variation in interest rates on investment spending, employing a large panel data set that links yields on outstanding corporate bonds to the issuer income and balance sheet statements. The bond price data -- based on trades in the secondary market -- enable us to construct a firm-specific measure of the user cost of capital based on the marginal cost of external finance as determined in the market for long-term corporate debt. Our results imply a robust and quantitatively important effect of the user cost of capital on the firm-level investment decisions. According to our estimates, a 1 percentage point increase in the user cost of capital implies a reduction in the investment rate of 50 to 75 basis points and, in the long run, a 1 percent reduction in the stock of capital.
\end{abstract}

\author{
Simon Gilchrist \\ Department of Economics \\ Boston University \\ 270 Bay State Road \\ Boston, MA 02215 \\ and NBER \\ sgilchri@bu.edu \\ Egon Zakrajsek \\ Division of Monetary Affairs \\ Federal Reserve Board \\ 20th Street \& Constitution Avenue, NW \\ Washington, D.C. 20551 \\ egon.zakrajsek@frb.gov
}




\section{Introduction}

The notion that business spending on fixed capital falls when interest rates rise is a theoretically unambiguous relationship that lies at the heart of the monetary transmission mechanism. Nevertheless, the presence of a robust negative relationship between investment expenditures and real interest rates - or the user cost of capital more generally - has been surprisingly difficult to document in actual data (e.g., Abel and Blanchard [1986] and Schaller [2006]). Similarly, the magnitude of the response of investment to changes in corporate tax policies is a key parameter that fiscal policy makers rely on when weighing the costs and benefits of altering the tax code. With the exception of Cummins, Hassett, and Hubbard [1994], whose methodology utilizes firm-level variation in investment expenditures within a context of a "natural" experiment, researchers have had a difficult time identifying the relationship between capital formation and changes in corporate tax policy (e.g., Schaller [2006] and Chirinko, Fazzari, and Meyer [1999, 2004]). ${ }^{1}$

The empirical difficulties associated with estimating the effects of changes in interest rates and corporate tax policies on business fixed investment are often blamed on a lack of identification. At the macroeconomic level in particular, long-term interest rates (through monetary policy actions) and corporate tax obligations (through investment tax credits or partial expensing allowances) are often lowered when investment spending is weak. ${ }^{2}$ In the extreme, the endogeneity between both monetary and fiscal policy actions and the macroeconomy may result in a positive relationship between investment expenditures and the user cost of capital.

In this paper, we revisit this apparent and long-standing empirical anomaly. We do so by constructing a new data set that links income and balance sheet information for about 900 large U.S. nonfinancial corporations to interest rates on their publicly-traded debt. Covering the last three decades, this new data set enables us to evaluate and to quantify empirically the relationship between firms' investment decisions and fluctuations in the firm-specific user cost of capital based on marginal financing costs as measured by the changes in secondary market prices of firms' outstanding bonds. Our results indicate that investment spending is highly sensitive - both economically and statistically - to movements in the firm-specific measure of the user cost of capital. The sensitivity of capital formation to changes in the user cost is robust to the inclusion of various measures of investment

\footnotetext{
${ }^{1}$ For extensive surveys of this topic, see Auerbach [1983] and Chirinko [1993]; see also Hassett and Hubbard [1997] and Devereux, Keen, and Schiantarelli [1994].

${ }^{2}$ Partial expensing allowances permit firms to deduct a portion of their newly purchased capital goods from their taxable income. In that sense, both an investment tax credit (ITC) and an expensing allowance raise the firm's after-tax income when the firm purchases capital goods. The two tax policies, however, differ in that under partial expensing, the firm is not allowed to claim any future depreciation allowances for its expensed capital, whereas under an ITC, such a restriction is partly or wholly absent.
} 
opportunities emphasized by frictionless neoclassical models and to an estimation approach that controls for the potential endogeneity between investment and financial policy at the firm level.

The remainder of the paper is organized as follows. In Section 2, we provide a brief overview of the user-cost framework and review the evidence - at both the macro and micro levels - on the link between financing costs and investment spending. Section 3 describes our new data set and highlights its key feature. Section 4 outlines our panel-data econometric methodology, and Section 5 presents our benchmark results. In Section 6, we consider an alternative estimation approach that addresses the potential endogeneity between interest rates and investment decisions at the firm level. This approach involves constructing an instrument for the user cost of capital that explicitly controls for firm-specific expected default risk using both option-theoretic measures of default probabilities and external credit ratings of firms' debt. Section 7 concludes.

\section{Empirical Framework}

In this section, we briefly outline the user-cost framework that motivates our empirical analysis. We assume that output of the firm in period $t$ - denoted by $Y_{t}$-is a CES function of capital $\left(K_{t}\right)$ and variable inputs $\left(L_{t}\right):^{3}$

$$
Y_{t}=\left(a K_{t}^{\sigma}+b L_{t}^{\sigma}\right)^{1 / \sigma}
$$

where $0<a, b<1$ and $\sigma \leq 1$. Letting $C_{t}^{K}$ denote the cost of capital in period $t$, then the firm's desired capital stock $K_{t}^{*}$ satisfies the optimality condition

$$
a\left(\frac{Y_{t}}{K_{t}^{*}}\right)^{1-\sigma}=C_{t}^{K}
$$

Assuming a simple partial adjustment between actual and desired capital implies the following log-specification for the growth rate of the capital stock:

$$
\Delta \ln K_{t}=\eta+\lambda\left[\ln \left(\frac{Y_{t}}{K_{t}}\right)-\left(\frac{1}{1-\sigma}\right) \ln C_{t}^{K}\right],
$$

where the parameter $0<\lambda<1$ measures the speed of adjustment to the desired stock of capital and $1 /(1-\sigma)$ is the long-run elasticity of capital with respect to the user cost. The partial adjustment model is typically implemented empirically with a variant of the

\footnotetext{
${ }^{3}$ We adopt the convention that the time subscript $t$ on stock variables indicates the beginning of the period - that is, $K_{t}$ denotes the stock of capital at the beginning of period $t$.
} 
following regression

$$
\Delta \ln K_{t}=\eta+\eta_{y} \ln \left(Y_{t} / K_{t}\right)+\eta_{c} \ln C_{t}^{K}+\epsilon_{t},
$$

where $\epsilon_{t}$ is a zero-mean random disturbance. In equation 1 , the coefficient ratio

$$
-\frac{\eta_{c}}{\eta_{y}}=\frac{1}{1-\sigma}
$$

identifies the long-run elasticity of capital with respect to the user cost. With Cobb-Douglas production, $\sigma=0$, and the long-run elasticity of capital with respect to the user cost is unity. If $-\frac{\eta_{c}}{\eta_{y}}<1$, then $\sigma<0$, implying that capital and labor are less substitutable than in the Cobb-Douglas case. By contrast, if $-\frac{\eta_{c}}{\eta_{y}}>1$, then $\sigma>0$, implying greater substitutability of capital and labor compared with the Cobb-Douglas production function.

In the neoclassical user-cost framework, pioneered by the seminal work of Hall and Jorgenson [1967], the incentive to purchase physical capital depends not only on the financial costs, but also on the price of investment goods relative to the price of output, the rate at which capital depreciates, any expected gains or losses associated with capital purchases, and the tax treatment of both capital purchases and the capital income. Formally, the user cost of capital in period $t$ is given by

$$
C_{t}^{K}=\frac{P_{t}^{I}}{P_{t}^{Y}}\left(\left(1-\tau_{t}\right) r_{t}+\delta_{t}-E_{t}\left[\frac{\Delta P_{t+1}^{I}}{P_{t}^{I}}\right]\right)\left(\frac{1-\mathrm{ITC}_{t}-\tau_{t} z_{t}}{1-\tau_{t}}\right)
$$

where $E_{t}$ denotes the conditional expectation operator based on the information available at the beginning of period $t$.

Equation 2 combines the effects of the relative price of investment goods, the rate of return on financial assets, the depreciation rate, the capital gains term, and lastly, the tax considerations. Specifically, $P_{t}^{I} / P_{t}^{Y}$ denotes the price of investment goods relative to the price of output; $\left(1-\tau_{t}\right) r_{t}$ is the post-tax-interest being tax deductible - nominal rate of interest; $\delta_{t}$ is the time-varying rate of fixed capital depreciation; and $E_{t}\left(\Delta P_{t+1}^{I} / P_{t}^{I}\right)$ denotes any expected capital gains (or losses) stemming from the purchase of investment goods. The last term in equation 2 captures tax considerations associated with the purchase of physical capital. In particular, ITC $_{t}$ is the tax credit rate allowed on investment expenditures, $\tau_{t}$ is the corporate tax rate, and $z_{t}$ captures the present value of the depreciation deduction that can be subtracted from income for tax purposes.

To date, empirical research on the effects of fluctuations in the cost of capital on investment spending has encompassed three types of approaches: user-cost specifications, "natural experiment" analysis, and Q-theoretic frameworks. In the user-cost specifications, the empirical regression of interest is formulated as some variant of equation 1 (e.g., Bernanke, 
Bohn, and Reiss [1988] and Oliner, Rudebusch, and Sichel [1995]). ${ }^{4}$ Other formulations such as Caballero [1994], Tevlin and Whelan [2003], and Schaller [2006] exploit cointegrating relationships to identify the long-run effect of the cost of capital on investment, an approach that relies heavily on the fact that the relative price of capital goods is non-stationary. In general, changes in other components of the user cost-namely, interest rates and tax terms - play a modest, if any, role as determinants of investment spending in time-series models.

Recent work by Chirinko, Fazzari, and Meyer [2004] combines long-run analysis with firm-level panel data estimation techniques to estimate the elasticity of capital to the user cost. Reported estimates of the long-run elasticity in this literature are frequently lower than unity and, moreover, tend to be estimated with considerable imprecision. Importantly, these panel-data studies rely on aggregate interest rates when constructing the user cost. Thus, cross-sectional variation in the cost of capital is obtained primarily from capital goods prices that are industry specific and, to some extent, from tax effects that vary by industry owing to cross-sectional variation in depreciation rates.

The natural experiments approach adopted by Cummins, Hassett, and Hubbard [1994] focuses on episodes where tax changes are comparatively large and account for nearly all of the variation in the cost of capital. During such episodes, the elasticity of investment demand with respect to the user cost is estimated to be quite high. More recently, House and Shapiro [2006] analyze the impact of recent corporate tax changes - as measured by bonus depreciation allowances - and document a significant user-cost effect at the industry level. By relying on specific tax episodes, however, this strand of research has been unable to provide an explicit link between interest rates and investment spending.

Q-theoretic specifications rely on a formal description of adjustment costs, along with assumptions on production technology, to obtain an empirical relationship between investment and a tax-adjusted measure of Tobin's Q, which is typically constructed from stock market data (e.g., Salinger and Summers [1983]). Given the well-documented empirical failure of the Q-theory, this vein of research provides little guidance to either the short- or the long-run sensitivity of investment to the cost of capital. Abel and Blanchard [1986], by contrast, rely on a vector auto-regression (VAR) forecasting system-rather than the stock market - to construct proxies for future investment opportunities. Their VAR-based framework considers a linearized model that allows interest rates and output to have independent effects on investment. Although the estimated response of investment with respect to output is high, the estimated response of investment to interest rates is essentially zero, a finding consistent with that obtained by Shapiro [1986] from the direct estimation of the

\footnotetext{
${ }^{4}$ The empirical implementation generally includes lags of the dependent variable, lags of the outputcapital ratio, and lags of the user cost as additional regressors. Early examples of this approach include Hall and Jorgenson [1967] and Eisner and Nadiri [1968].
} 
Euler equations for factor demand.

In a recent paper, Philippon [2007] provides an alternative interpretation of the Q-theory of investment that utilizes information from the corporate bond market - as opposed to the the equity market - to construct an empirical proxy for Q. Because bond prices, just like equity prices, incorporate news about the firm's future profitability, Philippon [2007] shows that bond prices are proportional to $\mathrm{Q}$ under some mild assumptions for the stochastic process of aggregate shocks. According to his results, the empirical performance of the Q-theory based on corporate bond yields is considerably better compared with its equitybased counterpart - the yield-based proxy for Q explains more than a half of the volatility in aggregate investment in the post-war U.S. data and delivers economically plausible estimates of adjustment costs.

In our approach, we rely on firm-level data and use yields on the firm's outstanding senior unsecured bonds trading in the secondary market to construct the user cost of capital in equation 2. For our benchmark results, which are discussed in Section 5, we regress firm-level investment spending on measures of the marginal product of capital and our estimate of the user cost, a measure that incorporates heterogeneity in interest rates across firms (and time). The validity of this approach hinges importantly on two related questions: What are the potential sources of heterogeneity in interest rates across firms, and how does such crosssectional heterogeneity influence investment financing costs? According to the standard asset pricing theory, cross-sectional heterogeneity in interest rates reflects differences in risk factors, liquidity premiums, or default risk across firms. Whereas risk factors and liquidity premiums influence financing costs but are exogenous with respect to the firm's investment policy, default risk affects the cost of funds only if bankruptcy entails a dead-weight loss. In this case, default risk may be endogenous to the firm's investment policy; moreover, it may be correlated with unobserved variation in investment opportunities. Controlling for both the endogeneity and information content of default risk motivates the empirical analysis provided in Section 6.

Our paper is most closely related to the recent work of Guiso, Kashyap, Panetta, and Terlizzese [2002], who rely on firm-specific variation in bank lending rates to estimate the effect of financial costs on investment decisions of a large panel of Italian firms. Although Guiso et al. find no effect of interest rates on investment spending using OLS techniques, they document a negative relationship between interest rates and investment when using bank-specific determinants of loan supply as instruments. Whereas Guiso et al. analyze the investment behavior of small non-publicly-traded Italian firms for which non-price loans terms are likely as important as the lending rate, our data, by contrast, focuses on large publicly-traded U.S. firms that borrow extensively in the corporate cash market, and whose combined investment spending broadly matches the investment dynamics in the U.S. econ- 
omy as a whole. In addition, our estimates imply a strong negative relationship between the user cost and investment when using both simple OLS methods and an IV approach that takes into account the endogeneity and information content of firm-specific default risk.

\section{Data Description}

Our data set is an unbalanced panel of about 900 publicly-traded firms in the U.S. nonfarm nonfinancial corporate sector covering the period 1973 to 2005. The distinguishing feature of these firms is that a part of their long-term debt - in many cases, a significant portion - is in the form of bonds that are actively traded in the secondary market. For these firms, we have linked monthly market prices of their outstanding securities to annual income and balance sheet statements from Compustat. We now turn to the construction of our key variables: firm-specific interest rates and the associated user cost of capital and key income and balance sheet variables.

\subsection{Sources and Methods}

\subsubsection{Bond Yields}

We obtained month-end market prices of outstanding long-term corporate bonds from the Lehman/Warga (LW) and Merrill Lynch (ML) databases. These two data sources include prices for a significant fraction of dollar-denominated bonds publicly issued in the U.S. corporate cash market. The ML database is a proprietary data source of daily bond prices that starts in 1997. Focused on the most liquid securities, bonds in the ML database must have a remaining term-to-maturity of at least two years, a fixed coupon schedule, and a minimum amount outstanding of $\$ 100$ million for below investment-grade and $\$ 150$ million for investment-grade issuers. By contrast, the LW database of month-end bond prices has a somewhat broader coverage and is available from 1973 through mid-1998 (see Warga [1991] for details).

To ensure that we are measuring long-term financing costs of different firms at the same point in their capital structure, we limited our sample to only senior unsecured issues. For the securities carrying the senior unsecured rating and with market prices in both the LW and LM databases, we spliced the option-adjusted effective yields at month-end - a component of the bond's yield that is not attributable to embedded options - across the two data sources. To calculate the credit spreads at each point in time, we matched the yield on each individual security issued by the firm to the estimated yield on the Treasury coupon security of the same maturity. The month-end Treasury yields were taken from the daily estimates of the U.S. Treasury yield curve reported in Gürkaynak, Sack, and Wright [2006]. To mitigate the effect of outliers on our analysis, we eliminated all observations with 
Table 1: Summary Statistics of Bond Characteristics

\begin{tabular}{|c|c|c|c|c|c|}
\hline Variable & Mean & StdDev & Min & Median & Max \\
\hline \# of bonds per firm/month & 3.39 & 4.16 & 1.00 & 2.00 & 57.00 \\
\hline Mkt. Value of Issue $^{a}$ (\$mil.) & 285.3 & 322.5 & 1.21 & 210.5 & $6,771.1$ \\
\hline Maturity at Issue (years) & 14.1 & 9.5 & 2.0 & 10.0 & 50.0 \\
\hline Duration (years) & 6.41 & 2.91 & 0.01 & 6.03 & 29.5 \\
\hline S\&P Credit Rating & - & - & $\mathrm{D}$ & A3 & AAA \\
\hline Coupon Rate (pct) & 7.67 & 2.13 & 0.00 & 7.42 & 16.63 \\
\hline Nominal Yield (pct) & 8.00 & 2.44 & 1.39 & 7.67 & 24.06 \\
\hline Real Yield ${ }^{b}$ (pct) & 4.83 & 1.81 & -3.47 & 4.71 & 15.27 \\
\hline Credit Spread $^{c}$ (bps) & 149 & 135 & 0 & 105 & 1000 \\
\hline \multicolumn{6}{|c|}{ Panel Dimensions } \\
\hline \multicolumn{6}{|c|}{ Obs. $=316,984 \quad N=5,800$ bonds } \\
\hline
\end{tabular}

Notes: Sample period: Monthly data from January 1973 to December 2005. Sample statistics are based on trimmed data (see text for details).

${ }^{a}$ Market value of the outstanding issue deflated by the CPI.

${ }^{b}$ Nominal yield less the percent change in previous month's core CPI from twelve months prior.

${ }^{c}$ Measured relative to comparable maturity Treasury yield (see text for details).

negative credit spreads and with spreads greater than 1,000 basis points. This selection criterion yielded a sample of 5,800 individual securities, issued by 926 nonfinancial firms during the 1973-2005 period.

Table 1 contains summary statistics for the key characteristics of bonds in our sample. Note that a typical firm has only a few senior unsecured issues outstanding at any point in time - the median firm, for example, has two such issues trading at any given month. This distribution, however, exhibits a significant positive skew, as some firms can have more than fifty different senior unsecured bond issues trading in the market at a point in time. The distribution of the real market values of these issues is similarly skewed, with the range running from $\$ 1.2$ million to more than $\$ 6.7$ billion. Not surprisingly, the maturity of these debt instruments is fairly long, with the average maturity at issue of about 14 years. Because corporate bonds typically generate significant cash flow in the form of regular coupon payments, the effective duration is considerably shorter, with both the average and the median duration of about 7.5 years. Although our sample spans the entire spectrum of credit quality - from "single D" to "triple A" - the median bond/month observation, at "A3," is solidly in the investment-grade category.

Turning to returns, the (nominal) coupon rate on these bonds averaged 7.67 percent 
during our sample period, while the average total nominal return, as measured by the nominal effective yield, was 8 percent per annum. Reflecting the wide range of credit quality, the distribution of nominal yields is quite wide, with the minimum of about 1.4 percent and the maximum of more than 24 percent. In real terms, these bonds yielded 4.8 percent per annum, on average, during our sample period, with the standard deviation of 1.81 percent. $^{5}$ Relative to Treasuries, an average bond in our sample generated a return of about 150 basis points above the comparable-maturity risk-free rate, with the standard deviation of 135 basis points.

Figure 1 depicts the time-series evolution of the cross-sectional distribution of nominal yields for the bonds in our sample. For comparison, the figure also shows the nominal yield on all corporate bonds carrying the Moody's Baa credit rating. As evidenced by the closeness of the 95th and 5th percentiles (the shaded band), there is relatively little crosssectional dispersion in corporate yields until the second half of the 1980s. The narrowness of the distribution before the mid-1980s reflects the fact that the corporate cash market during this time period was limited largely to investment-grade issues at the upper end of the credit-quality spectrum. Indeed, during this period, a significant majority of yields in our sample are consistently below the yield on the Baa-rated corporate bonds, a category of debt that sits at the bottom rung of the investment-grade ladder.

The increase in the cross-sectional dispersion of corporate interest rates that began in the second half of the 1980s coincided with the deepening of the market for "junk-rated" corporate debt. The drift of the aggregate Baa yield towards the center of the cross-sectional distribution is another piece of evidence pointing to the increased ability of riskier firms to tap the corporate cash market. The amount of cross-sectional heterogeneity in our sample is particularly apparent between 2000 and 2003, a period in which the effects of a cyclical downturn were compounded by a slew of corporate scandals. This combination of the crosssectional heterogeneity in external financing costs with considerable cyclical fluctuations are factors that should enhance our ability to identify variation in the investment supply curve and thus help us to estimate more precisely the interest sensitivity of investment demand.

\footnotetext{
${ }^{5}$ To covert the monthly nominal bond yields into real terms, we employed a simplifying assumption that the expected inflation in period $t$ is equal to the last period's realized annual core CPI inflation. Specifically, letting $i_{j t}^{k}$ denote the nominal yield (in percent per annum) on bond $k$ of firm $j$ at the end of month $t$, we computed the corresponding real yield $r_{j t}^{k}$ according to

$$
r_{j t}^{k}=i_{j t}^{k}-100 \times \ln \left(\frac{\mathrm{CPI}_{t-1}}{\mathrm{CPI}_{t-13}}\right)
$$

where CPI denotes the level of the Consumer Price Index, excluding its food and energy components.
} 
Figure 1: The Evolution of Corporate Bond Yields

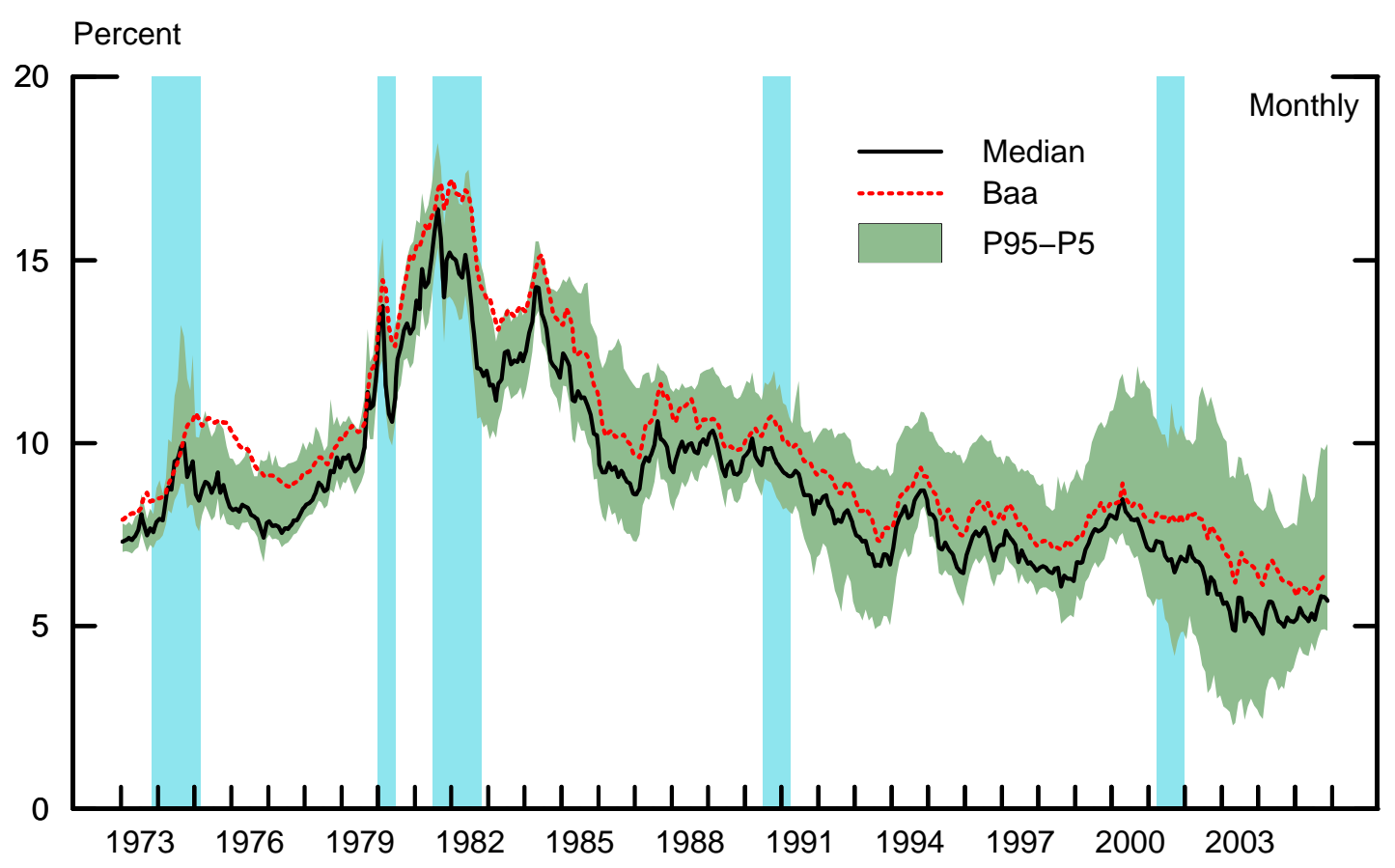

Notes: This figure depicts the evolution of the cross-sectional distribution of nominal bond yields in our sample. The solid line shows the market-value-weighted median of the cross-sectional distribution of yields, while the shaded band shows a corresponding measure of cross-sectional dispersion, calculated as the difference between the market-value-weighted 95th percentile (P95) and the market-value-weighted 5th percentile (P5) of the distribution. The dotted line shows the aggregate yield on all Baa-rated corporate bonds. The shaded vertical bars denote the NBER-dated recessions.

\subsubsection{User Cost, Income, and Balance Sheet Data}

We matched these 5,800 corporate securities with the issuer's annual income and balance sheet data from Compustat. Figure 2 compares the aggregate dynamics of investment for the resulting sample of 926 firms with those of the U.S. economy as a whole. Note that until the mid-1980s, the growth of aggregate real investment for the firms in our sample differed noticeably from the dynamics of real investment as reported in the National Income and Product Accounts (NIPA). The differences between the two series largely reflect the relatively small number of firms in our sample during this period-indeed, for the first 6 years of our sample period, our panel includes only about 50 firms per year. By the mid-1980s, however, the number of firms of our panel has risen to about 200 per year, and the two series in Figure 2 became much more closely correlated.

The evidence presented in Figures 1 and 2 suggests that we restrict our empirical analysis to the last two decades of our sample period. First, the opening of the corporate bond market 
Figure 2: The Growth of Business Fixed Investment

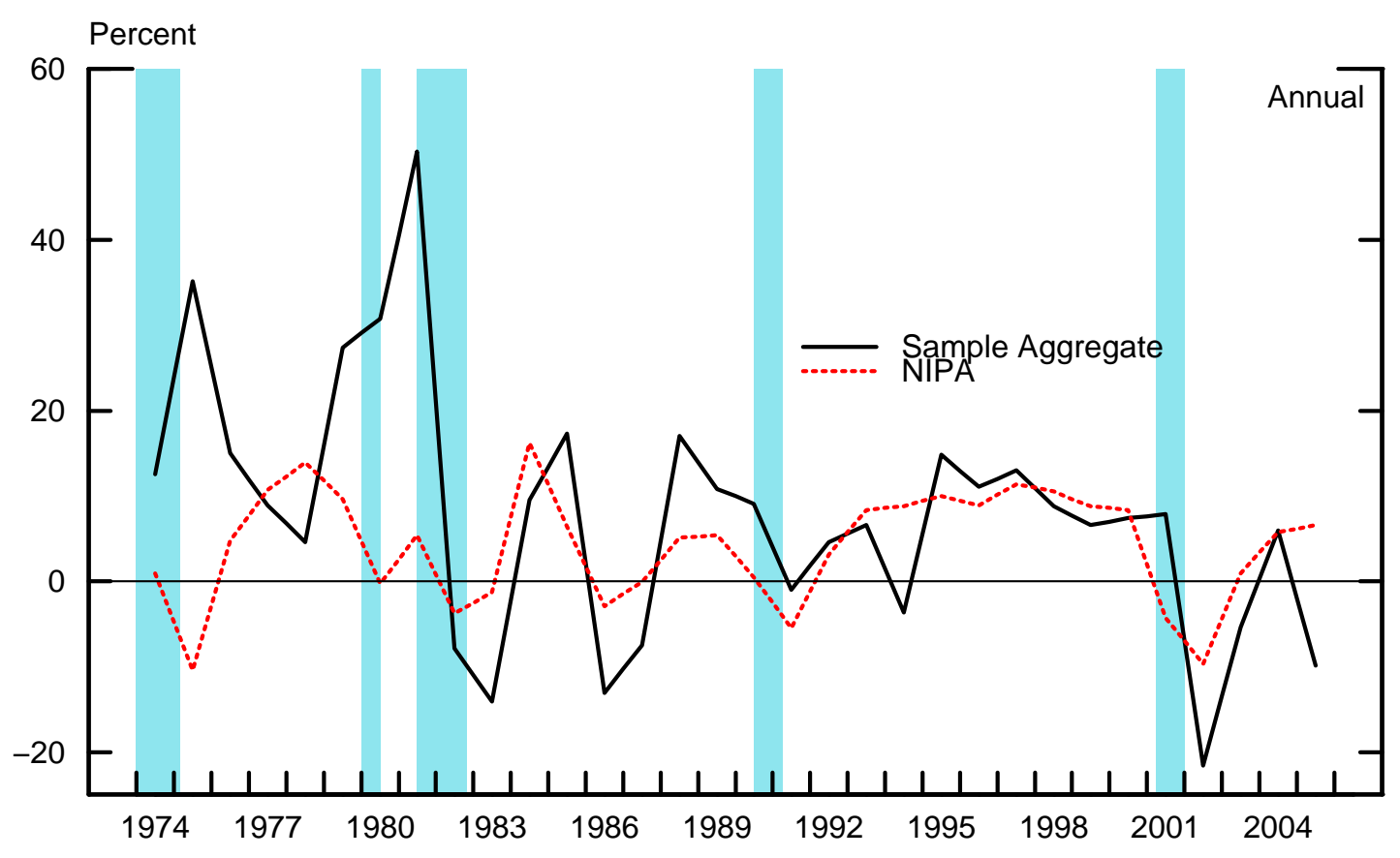

Notes: The solid line shows the growth rate of the aggregate real capital expenditures for the firms in our sample. The dotted line shows the growth rate of real business fixed investment measured by the NIPA. Both variables are in chain-weighted $(2000=100)$ dollars. The shaded vertical bars denote the NBER-dated recessions.

to lower-rated credits, a process that started in the mid-1980s, likely mitigates the sample selection bias to some extent during this period. Second, starting in the mid-1980s, the aggregate investment for our sample of firms tracks fairly closely the investment dynamics reported in NIPA, an indication that empirical results based on this period have implications for the U.S. economy as a whole. And lastly, the 3/4-digit North American Industrial Classification System (NAICS) data used to construct the industry-specific components of the user cost of capital - namely, the relative price of new capital goods, the depreciation rate, the capital gains, and the tax considerations - are available only from 1987 onward.

In our analysis, the key component of the user cost of capital in equation 2 is the posttax nominal interest rate $\left(1-\tau_{t}\right) r_{j t}$, a component that varies across both firms and time. As noted in Table 1, effective duration varies widely across our sample of bonds. To ensure that neither the cross-sectional nor the time-series variation in our firm-specific measure of the user cost reflects variation in the term premiums, we subtracted from each bond yield an estimate of the term premium derived from the Treasury yield curve. Specifically, let $r_{j t}^{h}$ denote the effective (nominal) yield of bond $h$ (issued by firm $j$ ) on day $t$ with the duration 
equal to $d_{j t}^{h}$ and let $d^{*}$ denote the "target" duration. Our duration-adjusted yield is then given by

$$
\tilde{r}_{j t}^{h}=r_{j t}^{h}-\left[y_{t}\left(d^{*}\right)-y_{t}\left(d_{j t}^{h}\right)\right]
$$

where $y_{t}(d)$ denotes the (nominal) yield, on day $t$, on a zero-coupon Treasury security of maturity $d$. We set our target duration $d^{*}$ equal to 7 years - around the median duration in our sample - and we used the daily (month-end) estimates of the zero-coupon Treasury yield curve from Gürkaynak et al. [2006] to compute the term premium $y_{t}\left(d^{*}\right)-y_{t}\left(d_{j t}^{k}\right)$.

Because our income and balance sheet data are available only at an annual frequency, we converted the monthly bond yields to firm-level interest rates in two steps. First, we calculated an average bond yield for firm $j$ in month $t$ by averaging the duration-adjusted yields on the firm's outstanding bonds in that month, using market values of bond issues as weights:

$$
\tilde{r}_{j t}=\sum_{h=1}^{H_{j t}} w_{j t}^{h} \tilde{r}_{j t}^{h},
$$

where $H_{j t}$ denotes the number of outstanding bond issues of firm $j$ at the end of month $t$ and $0<w_{j t}^{h} \leq 1$ is the weight for bond issue $h$. To convert these firm-level rates to annual frequency, we then averaged the available monthly yields over the twelve months of the firm's fiscal year. ${ }^{6}$ We used these firm-specific interest rates to construct an estimate of the user cost capital $C_{j t}^{K}$ in equation 2 . As noted above, the remaining components of the user cost - namely, the relative price of investment goods, the depreciation rate, the capital gains, and the tax considerations - are allowed to vary across 52 industries as defined by $3 / 4$-digit NAICS. (Appendix A contains a detailed description of all the industry components of the user cost of capital.)

Table 2 contains summary statistics for selected variables in our final panel data set. (Appendix B contains a detailed description of the construction of our key variables.) Although our sample focuses on firms that have both equity and a portion of their long-term debt traded in capital markets, firm size - measured by sales or market capitalizationvaries widely in our sample. Not surprisingly, though, most of the firms in our data set are quite large. The median firm has annual real sales of almost $\$ 4$ billion and a real market capitalization of about $\$ 1.9$ billion. Despite the fact that firms in our sample generally have only a few senior unsecured bond issues trading at any given point in time, this form of publicly-traded debt represents a significant portion of the long-term debt on their books. The ratio of the par value of traded bonds outstanding to the book value of total long-term

\footnotetext{
${ }^{6}$ For example, for a firm with fiscal year ending in December, the average interest rate in year $t$ is calculated as an average of the available monthly yields from January through December of the same year. For a firm with fiscal year ending in, say, June, the average interest rate in year $t$ is calculated as an average of the available monthly yields from July of year $t-1$ through June of year $t$.
} 
Table 2: Summary Statistics for Selected Variables

\begin{tabular}{|c|c|c|c|c|c|}
\hline Variable & Mean & StdDev & Min & Median & Max \\
\hline Sales (\$bil.) & 9.34 & 18.80 & $<.01$ & 3.89 & 275.8 \\
\hline Mkt. Capitalization (\$bil.) & 5.89 & 12.46 & $<.01$ & 1.89 & 172.5 \\
\hline Par Value to L-T Debt ${ }^{a}$ & 0.45 & 0.25 & $<.01$ & 0.42 & 1.00 \\
\hline Investment to Capital $^{b}$ & 0.18 & 0.12 & 0.01 & 0.15 & 1.00 \\
\hline Sales to Capital ${ }^{c}$ & 3.50 & 3.23 & 0.17 & 2.65 & 25.0 \\
\hline Profits to Capital $^{d}$ & 0.47 & 0.39 & -0.46 & 0.36 & 2.99 \\
\hline Tobin's $Q^{e}$ & 1.62 & 0.85 & 0.44 & 1.37 & 15.3 \\
\hline User Cost of Capital & 0.15 & 0.05 & 0.04 & 0.15 & 0.35 \\
\hline \multicolumn{6}{|c|}{ Panel Dimensions } \\
\hline $\begin{array}{r}\text { Obs. }= \\
\text { Min. Tenure }=1 \quad \text { Me }\end{array}$ & 398 & $\begin{array}{l}\mathrm{N}=896 \\
\text { ure }=6\end{array}$ & $\begin{array}{l}\text { rms } \\
\text { Max. }\end{array}$ & & \\
\hline
\end{tabular}

Notes: Sample period: Annual data from 1987 to 2005. Sample statistics are based on trimmed data, and real (i.e., inflation-adjusted) variables are expressed in 2000 dollars (see Appendix B for details).

${ }^{a}$ The ratio of the par value of all of the firm's senior unsecured bonds from the LW/ML database to the book value of its total long-term debt.

${ }^{b}$ Real investment in period $t$ relative to real capital stock at the beginning of period $t$.

${ }^{c}$ Real sales in period $t$ relative to real capital stock at the beginning of period $t$.

${ }^{d}$ Real operating income (loss) in period $t$ relative to real capital stock at the beginning of period $t$.

${ }^{e}$ The ratio of the sum of the market value of equity and the book value of total liabilities at the end of period $t$ to the book value of total assets at the end of period $t$.

debt on firms' balance sheet is, on average, almost one-half (0.47), indicating that market prices on these outstanding securities likely provide an accurate gauge of the marginal investment financing costs. Taking into account the remaining factors that influence the cost of capital yields an average user cost equal to 0.15 , with the standard deviation of 0.05 .

\section{Empirical Specification of Investment Equation}

Our empirical strategy involves regressing investment on measures of economic fundamentals and a firm-specific estimate of the user cost of capital calculated using our duration-adjusted bond yields. In addition to our measures of the user cost and investment fundamentals, we control for firm and time fixed effects in the regression analysis. Time fixed effects capture a common investment component reflecting macroeconomic factors, which can influence firm-level investment through either output or interest rates. We include firm fixed effects in the regression to control for differences in the average investment rate across firms. 
Such heterogeneity may arise either because the average level of fundamentals differs, or because the cost of investing differs across firms in some systematic way not captured by our empirical proxies. Finally, for the sake of robustness, we also allow for serial correlation in the investment process by including lagged investment rate among the explanatory variables.

Our baseline empirical investment equation is given by the semi-log specification motivated by the user-cost framework discussed above:

$$
\left[\frac{I}{K}\right]_{j t}=\beta_{1} \ln Z_{j t}+\beta_{2} \ln C_{j t}^{K}+\mu_{j}+\lambda_{t}+\epsilon_{j t},
$$

where $[I / K]_{j t}$ denotes the investment rate of firm $j$ in period $t$ (i.e., the ratio of real capital expenditures in period $t$ to the real capital stock at beginning of the period), $Z_{j t}$ is a variable that measures firm $j$ 's future investment opportunities (i.e., economic fundamentals), $C_{j t}^{K}$ is the firm-specific user cost of capital, $\mu_{j}$ is the firm-specific fixed effect, and $\lambda_{t}$ is a time dummy. In our baseline case, we assume that the error term $\epsilon_{j t}$ is orthogonal to current and past values of $Z_{j t}$ and $C_{j t}^{K}$. To take into account the persistence of the investment process, we also consider a dynamic specification of the form:

$$
\left[\frac{I}{K}\right]_{j t}=\alpha\left[\frac{I}{K}\right]_{j, t-1}+\beta_{1} \ln Z_{j t}+\beta_{1} \ln C_{j t}^{K}+\mu_{j}+\lambda_{t}+\epsilon_{j t} .
$$

Because investment data are positively skewed - which may create heteroskedasticity in $\epsilon_{j t}$ across firms - we also consider a log-log specification, which replaces $I / K$ with $\ln (I / K)$ in equations 3 and 4.

In our baseline regressions, we eliminate the firm fixed effect $\mu_{j}$ using the standard "within" transformation. However, the presence of the lagged dependent variable on the right-hand side of equation 4 implies that the within-firm regression does not yield consistent parameter estimates. We therefore consider a forward mean-differenced transformation of equation 4 :

$$
\Delta_{t}^{T_{j}}\left[\frac{I}{K}\right]_{j t}=\alpha \Delta_{t}^{T_{j}}\left[\frac{I}{K}\right]_{j, t-1}+\beta_{1} \Delta_{t}^{T_{j}}\left(\ln Z_{j t}\right)+\beta_{2} \Delta_{t}^{T_{j}}\left(\ln C_{j t}^{K}\right)+\Delta_{t}^{T_{j}}\left(\lambda_{t}\right)+\Delta_{t}^{T_{j}}\left(\epsilon_{j t}\right),
$$

where $\Delta_{t}^{T_{j}}$ denotes the forward mean-differencing operator

$$
\Delta_{t}^{T_{j}}\left(X_{j t}\right) \equiv X_{j t}-\left[\frac{1}{T_{j}-k}\right] \sum_{k=t+1}^{T_{j}} X_{j k}
$$


This transformation induces a moving-average component into the original error term

$$
\Delta_{t}^{T_{j}}\left(\epsilon_{j t}\right)=\epsilon_{j t}-\left[\frac{1}{T_{j}-k}\right] \sum_{k=t+1}^{T_{j}} \epsilon_{j k}
$$

which nevertheless preserves the validity of instruments in the sense that if

$$
E\left[\epsilon_{j t} X_{j t} \mid \mu_{j}, \lambda_{t}\right]=0,
$$

then

$$
E\left[\Delta_{t}^{T_{j}}\left(\epsilon_{j t}\right) X_{j t} \mid \mu_{j}, \lambda_{t}\right]=0
$$

Hence, assuming that for $k \geq 0$

$$
E\left[\epsilon_{j t} \ln Z_{j, t-k} \mid \mu_{j}, \lambda_{t}\right]=E\left[\epsilon_{j t} \ln C_{j, t-k}^{K} \mid \mu_{j}, \lambda_{t}\right]=E\left[\epsilon_{j t}\left[\frac{I}{K}\right]_{j, t-1-k} \mid \mu_{j}, \lambda_{t}\right]=0,
$$

lagged values of $[I / K]_{j, t-1}$, along with current and lagged values of $\ln Z_{j t}$ and $\ln C_{j t}^{K}$, are valid instruments in the presence of the transformed error term $\Delta_{t}^{T_{j}}\left(\epsilon_{j t}\right)$. In practice, however, we do not use all the available lags as instruments, as distant lags are likely to be poor instruments. Specifically, our instrument set consists of lags 2 to 5 of $[I / K]_{j t}$ (or $\left.\ln [I / K]_{j t}\right)$ and lags 2 to 5 of both $\ln Z_{j t}$ and $\ln C_{j t}^{K}$.

In both the static and dynamic specifications, we measure investment fundamentals using either the current sales-to-capital ratio $[S / K]_{j t}$ or the operating-income-to-capital ratio $[\Pi / K]_{j t} \cdot{ }^{7}$ Following Gilchrist and Himmelberg [1998], we construct a measure of the marginal product of capital for firm $j$ at time $t$ as

$$
\operatorname{MPK}_{j t}^{S}=\phi_{s}\left[\frac{S}{K}\right]_{j t} \quad \text { or } \quad \operatorname{MPK}_{j t}^{\Pi}=\psi_{s}\left[\frac{\Pi}{K}\right]_{j t},
$$

where $\phi_{s}>0$ and $\psi_{s}>0$ are appropriately defined scaling factors that are specific to the industry $s$ in which the firm $j$ operates. These scaling constants capture the fact that sales-to-capital and operating-income-to-capital ratios vary substantially across industries, whereas in equilibrium, the return on capital should be equalized across industries (see Appendix B for details). We then set $Z_{j t}$ - our measure of investment fundamentals for firm $j$ - equal to each measure of the marginal product of capital.

Taking logs of $\mathrm{MPK}_{j t}^{S}$ is straightforward. It also implies that the scaling factor $\phi_{s}$ is subsumed in the firm-specific fixed effect $\mu_{j}$. Because operating income may be negative,

\footnotetext{
${ }^{7}$ Both the real sales and the real operating income in period $t$ are scaled by the real capital stock as of the beginning of period $t$.
} 
we use

$$
\ln Z_{j t}=\ln \left(\xi+\mathrm{MPK}_{j t}^{\Pi}\right)
$$

to measure fundamentals when using operating income as the measure of investment opportunities, where $\xi$ is chosen so that $\xi+\mathrm{MPK}_{j t}^{\Pi}>0$ for all $j$ and $t$. In this case, we first construct the scale-adjusted marginal product $\mathrm{MPK}_{j t}^{\Pi}$ and then compute $Z_{j t}$ for a given choice of $\xi$. In principal, estimated elasticities may depend on $\xi$. In practice, however, reasonable variation in $\xi$ has no effect on the estimated elasticities, and we confine our attention to estimates based on $\xi=0.5$. One drawback of both MPK measures is that they are not explicitly forward looking. However, under the assumption that economic fundamentals approximately follow an $\mathrm{AR}(1)$ process, the current value of the marginal product of capital summarizes its future path and may, therefore, provide a reasonable measure of future investment opportunities.

\section{Benchmark Results}

In this section, we present our benchmark results and examine their robustness using alternative specifications. Our benchmark results are based on the regression specification given in equation 3 and estimated over the 1987-2005 sample period. In addition to the overall user-cost term $\ln C_{j t}^{K}$, we also consider the separate effects of its two main components: the log of the industry-specific tax-adjusted relative price of new capital goods:

$$
\ln \left[\frac{P_{s t}^{I}}{P_{s t}^{Y}}\left(\frac{1-\mathrm{ITC}_{t}-\tau_{t} z_{s t}}{1-\tau_{t}}\right)\right]
$$

and the log of the firm-specific financial cost of capital:

$$
\ln \left[\left(1-\tau_{t}\right) \tilde{r}_{j t}+\delta_{s t}-E_{t}\left(\frac{\Delta P_{s, t+1}^{I}}{P_{s t}^{I}}\right)\right]
$$

To gauge the extent to which firm-specific variation in interest rates is useful in identifying the elasticity of investment demand with respect to the user cost of capital, we also consider a measure of the financial cost of capital calculated using a common interest rate. Specifically, we replace the firm-specific interest rate $\tilde{r}_{j t}$ in the financial cost of capital term with the (nominal) yield on Baa-rated corporate debt (see Figure 1); when constructed in this manner, the cross-sectional variation in the financial cost of capital is due entirely to differences in depreciation rates and expected capital gains across industries. Table 3 reports our baseline results for the semi-log specification, and Table 4 contains results for the log-log specification. In both tables, entries in columns 2 and 5 are based on the firmspecific measure of the financial cost of capital; entries in columns 3 and 5 , by contrast, are 
Table 3: Investment and the Cost of Capital (Static Specification, 1987-2005)

\begin{tabular}{|c|c|c|c|c|c|c|}
\hline \multirow[b]{2}{*}{ Variable } & \multicolumn{6}{|c|}{ Semi-Log Specification } \\
\hline & (1) & $(2)$ & $(3)$ & $(4)$ & $(5)$ & $(6)$ \\
\hline $\ln \mathrm{MPK}_{j t}^{S}$ & $\begin{array}{c}0.126 \\
(0.009)\end{array}$ & $\begin{array}{c}0.127 \\
(0.009)\end{array}$ & $\begin{array}{c}0.127 \\
(0.008)\end{array}$ & - & - & - \\
\hline $\ln \mathrm{MPK}_{j t}^{\Pi}$ & - & - & - & $\begin{array}{c}0.095 \\
(0.006)\end{array}$ & $\begin{array}{c}0.096 \\
(0.006)\end{array}$ & $\begin{array}{c}0.097 \\
(0.006)\end{array}$ \\
\hline $\ln C_{j t}^{K}$ & $\begin{array}{l}-0.113 \\
(0.016)\end{array}$ & - & - & $\begin{array}{l}-0.072 \\
(0.015)\end{array}$ & - & - \\
\hline Relative Price $^{a}$ & - & $\begin{array}{l}-0.126 \\
(0.023)\end{array}$ & $\begin{array}{l}-0.126 \\
(0.023)\end{array}$ & - & $\begin{array}{c}-0.084 \\
(0.020)\end{array}$ & $\begin{array}{l}-0.083 \\
(0.020)\end{array}$ \\
\hline Financial Cost ${ }^{b}$ & - & $\begin{array}{l}-0.095 \\
(0.015)\end{array}$ & $\begin{array}{l}-0.026 \\
(0.027)\end{array}$ & - & $\begin{array}{l}-0.054 \\
(0.017)\end{array}$ & $\begin{array}{c}0.017 \\
(0.023) \\
\end{array}$ \\
\hline L-R Elasticity $^{c}$ & $\begin{array}{l}-1.111 \\
(0.116)\end{array}$ & - & - & $\begin{array}{l}-1.323 \\
(0.293)\end{array}$ & - & - \\
\hline $\operatorname{Pr}>F^{d}$ & - & 0.240 & 0.003 & - & 0.220 & 0.000 \\
\hline$R^{2}$ (within) & 0.249 & 0.250 & 0.242 & 0.224 & 0.224 & 0.222 \\
\hline $\mathrm{BIC}^{e}$ & -14.70 & -14.70 & -14.63 & -14.49 & -14.48 & -14.46 \\
\hline Panel Dimensions & & Obs & 398 & $=898$ & $=7.1$ & \\
\hline
\end{tabular}

Notes: The dependent variable is the real investment rate $[I / K]_{j t}$. All specifications include firm fixed effects $\left(\mu_{j}\right)$ and time fixed effects $\left(\lambda_{t}\right)$ and are estimated by OLS. Heteroskedasticity- and autocorrelation-consistent asymptotic standard errors are computed according to Arellano [1987] and are reported in parentheses. Parameter estimates for $\ln \mathrm{MPK}^{\Pi}$ and the associated standard errors are adjusted for the fact that the $\log$ of $\mathrm{MPK}_{j t}^{\mathrm{I}}$ is computed as $\ln \left(0.5+\mathrm{MPK}_{j t}^{\mathrm{M}}\right)$.

${ }^{a}$ The industry-specific relative price of capital is adjusted for the tax treatment of capital expenditures (see text for details).

${ }^{b}$ In columns 2 and 5 , the financial cost of capital is constructed using firm-specific bond yields. In columns 3 and 6 , the financial cost of capital is constructed using the aggregate yield on Baa-rated corporate bonds (see text for details).

${ }^{c}$ Estimate of the long-run elasticity of capital with respect to the user cost (see text for details). Standard errors are computed according to the delta method.

${ }^{d} p$-value for the test of the null hypothesis that the coefficient on the tax-adjusted relative price of capital is equal to the coefficient on the financial cost of capital.

${ }^{e}$ Schwarz Bayesian Information Criterion (smaller is better).

based on the financial cost of capital calculated using the common Baa corporate yield.

According to entries in Tables 3 and 4, the firm-specific measure of the user cost of capital is an economically important and statistically significant explanatory variable for investment in all specifications. For either the semi-log or log-log specification (columns 1 and 4 in Tables 3 and 4), a 1 percentage point increase in the user cost of capital implies a reduction in the average rate of investment between 50 to 75 basis points, depending on the 
specification. The investment fundamentals - as measured by our proxies for the marginal product of capital - are also economically important determinants of capital spending, with coefficients that are estimated with considerable precision. In both the semi-log and log-log specifications, the coefficient on the user cost is essentially equal to (minus) the coefficient on the marginal product of capital. As a result, the long-run elasticity of capital with respect to the user cost, calculated as the ratio of these two elasticities, is estimated to be -1.11 and -1.32 in the semi-log specifications and -1.02 and -1.04 in the log-log specification. Note that from a statistical perspective, all estimates of the long-run elasticities are indistinguishable from unity, a result consistent with the Cobb-Douglas production technology.

We now consider the effect of decomposing the user cost into its separate components: the tax-adjusted price effect and the financial cost. The first set of estimates based on this exercise utilize firm-specific interest rates to construct the financial cost (columns 2 and 5 of Tables 3 and 4 . The second set of estimates, by contrast, relies on the common Baa interest rate (columns 3 and 6 of Tables 3 and 4 ).

When using firm-specific interest rates to construct the financial cost of capital, our estimates imply that both components of the user cost - the price effect and the financing cost - have economically large and statistically significant negative effects on investment. In addition, the estimated coefficients on the two components are very similar in size across all specifications. This result is especially apparent in the log-log specification, where the estimates of the price and financing cost effects are -0.758 and -0.686 , respectively, when using the sales-based measure of MPK, and -0.461 and -0.477 , when using the profit-based measure of MPK to control for the investment fundamentals. Indeed, we do not reject the restriction that the price and financing cost effects are equal in magnitude in all specifications. Moreover, we do not reject the restriction that these coefficients are equal and opposite in sign to the coefficient on the marginal product of capital. Thus all three variables - the marginal product of capital, the tax-adjusted relative price, and the financial cost - provide distinct information regarding investment fundamentals, and they all have essentially the same economic impact on the firm-level investment decisions. ${ }^{8}$ These results stand in sharp contrast to those obtained when we consider the effect of financial cost based on the common interest rate. Indeed, when using the aggregate Baa corporate yield to construct the financial cost of capital, we are unable to reject the hypothesis that the associated coefficient is zero in all specifications (columns 3 and 6 in Tables 3 and 4). These results clearly illustrate the difficulty of estimating the user-cost elasticity of investment demand in the absence of variation in interest rates across firms.

In summary, our benchmark estimates imply that movements in the user cost of capital

\footnotetext{
${ }^{8}$ As further confirmation of these results, we also considered regressions of the investment rate on each term separately. In all cases, we obtained coefficient estimates that were almost identical to those reported in columns 2 and 5 of Tables 3 and 4 .
} 
Table 4: Investment and the Cost of Capital (Static Specification, 1987-2005)

\begin{tabular}{|c|c|c|c|c|c|c|}
\hline \multirow[b]{2}{*}{ Variable } & \multicolumn{6}{|c|}{ Log-Log Specification } \\
\hline & (1) & $(2)$ & $(3)$ & $(4)$ & $(5)$ & (6) \\
\hline $\ln \mathrm{MPK}_{j t}^{S}$ & $\begin{array}{c}0.746 \\
(0.039)\end{array}$ & $\begin{array}{c}0.748 \\
(0.039)\end{array}$ & $\begin{array}{c}0.747 \\
(0.039)\end{array}$ & - & - & - \\
\hline $\ln \mathrm{MPK}_{j t}^{\Pi}$ & - & - & - & $\begin{array}{c}0.511 \\
(0.029)\end{array}$ & $\begin{array}{c}0.512 \\
(0.029)\end{array}$ & $\begin{array}{c}0.520 \\
(0.029)\end{array}$ \\
\hline $\ln C_{j t}^{K}$ & $\begin{array}{l}-0.729 \\
(0.078)\end{array}$ & - & - & $\begin{array}{l}-0.477 \\
(0.072)\end{array}$ & - & - \\
\hline Relative Price $^{a}$ & - & $\begin{array}{l}-0.758 \\
(0.114)\end{array}$ & $\begin{array}{l}-0.761 \\
(0.114)\end{array}$ & - & $\begin{array}{l}-0.488 \\
(0.095)\end{array}$ & $\begin{array}{l}-0.488 \\
(0.096)\end{array}$ \\
\hline Financial $\mathrm{Cost}^{b}$ & - & $\begin{array}{l}-0.686 \\
(0.089)\end{array}$ & $\begin{array}{l}-0.222 \\
(0.154)\end{array}$ & - & $\begin{array}{l}-0.459 \\
(0.100)\end{array}$ & $\begin{array}{c}0.045 \\
(0.126)\end{array}$ \\
\hline L-R Elasticity $^{c}$ & $\begin{array}{l}-1.023 \\
(0.116)\end{array}$ & - & - & $\begin{array}{l}-1.072 \\
(0.177)\end{array}$ & - & - \\
\hline $\operatorname{Pr}>F^{d}$ & - & 0.605 & 0.004 & - & 0.827 & 0.001 \\
\hline$R^{2}$ (within) & 0.308 & 0.308 & 0.293 & 0.244 & 0.244 & 0.237 \\
\hline $\mathrm{BIC}^{e}$ & 56.38 & 56.46 & 57.84 & 62.02 & 62.11 & 62.71 \\
\hline Panel Dimensions & & Obs & 398 & $=898$ & $=7.1$ & \\
\hline
\end{tabular}

Notes: The dependent variable is the $\log$ of the real investment rate $\ln [I / K]_{j t}$. All specifications include firm fixed effects $\left(\mu_{j}\right)$ and time fixed effects $\left(\lambda_{t}\right)$ and are estimated by OLS. Heteroskedasticityand autocorrelation-consistent asymptotic standard errors are computed according to Arellano [1987] and are reported in parentheses. Parameter estimates for $\ln \mathrm{MPK}^{\Pi}$ and the associated standard errors are adjusted for the fact that the $\log$ of $\mathrm{MPK}_{j t}^{\Pi}$ is computed as $\ln \left(0.5+\mathrm{MPK}_{j t}^{\Pi}\right)$.

${ }^{a}$ The industry-specific relative price of capital is adjusted for the tax treatment of capital expenditures (see text for details).

${ }^{b}$ In columns 2 and 5 , the financial cost of capital is constructed using firm-specific bond yields. In columns 3 and 6 , the financial cost of capital is constructed using the aggregate yield on Baa-rated corporate bonds (see text for details).

${ }^{c}$ Estimate of the long-run elasticity of capital with respect to the user cost (see text for details). Standard errors are computed according to the delta method.

${ }^{d} p$-value for the test of the null hypothesis that the coefficient on the tax-adjusted relative price of capital is equal to the coefficient on the financial cost of capital.

${ }^{e}$ Schwarz Bayesian Information Criterion (smaller is better).

have a strong negative effect on investment spending. Furthermore, the tax-adjusted relative price of investment goods and the financial cost of capital constructed using firm-specific interest rates contain independent information about the marginal cost of investment. According to our estimates, investment responds to the changes in marginal costs in essentially the same manner as it does to the changes in economic fundamentals, as measured by our proxies for the marginal product of capital. As a result, the long-run elasticity of capital 
with respect to the user cost is estimated to be unity.

\subsection{Alternative Specifications}

We now consider two alternative investment specifications. First, we allow for richer dynamics in the investment process by including a lagged dependent variable in the regression equation. Second, we allow the response of investment to both the fundamentals and the user cost of capital to differ across sectors. In both alternatives, we confine our attention to investment equations that include the marginal product of capital and the user cost as explanatory variables.

Table 5 reports coefficient estimates of the forward mean-differenced dynamic specification given in equation 4. As expected, the inclusion of the lagged investment rate tends to reduce somewhat the coefficient estimates for both the user cost and the marginal product of capital. The two coefficients, however, are still economically important and highly statistically significant in all specifications. Moreover, taking account of investment dynamics - that is, dividing the coefficients on the user cost and the marginal product of capital by $(1-\alpha)$ - actually implies a greater sensitivity of investment to both the user cost and fundamentals compared with the static case. Consistent with our benchmark results, the estimated long-run elasticity of capital with respect to the user cost is again close to unity.

Results in Table 6 are based the specification that allows the coefficient on the marginal product of capital and the user cost to vary across sectors based on 2-digit NAICS. ${ }^{9}$ For the sake of brevity, we report results for the log-log specification only, using $\mathrm{MPK}^{\Pi}$ as our measure of investment fundamentals. According to the entries in the table, the elasticity of investment to the user cost of capital is negative and statistically significant in all sectors, except in the information sector. ${ }^{10}$ Thus, our finding that an increase in the user cost has a strong negative impact on investment spending is broad-based and is not driven by a small number of observations or data from a single sector. By far, the two largest sectors in our sample - both in terms of number of firms and percentage of economic activityare the nondurable and durable goods manufacturing. ${ }^{11}$ For these two sectors, our results

\footnotetext{
${ }^{9}$ Because of a small number of service firms in our panel, our definition of the service sector includes the following 2-digit NAICS sectors: Professional, Scientific, and Technical Services (54); Administrative and Support and Waste Management and Remediation Services (56); Healthcare and Social Assistance (62); Arts, Entertainment, and Recreation (71); Accommodation and Food Services (72); and Other Services, except Public Administration (81).

${ }^{10}$ The information sector (NAICS 2-digit code 51) does not include the information technology (IT) industries, which fall into durable goods manufacturing. The information sector includes the following sub-sectors: Publishing Industries, except Internet; Motion Picture and Sound Recording Industries; Broadcasting, except Internet; Telecommunications; Internet Service Providers; and Other Information Services.

${ }^{11}$ The 434 manufacturing firms account for 51 percent of real capital expenditures and 60 percent of real sales during our sample period.
} 
Table 5: Investment and the Cost of Capital (Dynamic Specification, 1987-2005)

\begin{tabular}{|c|c|c|c|c|}
\hline \multirow[b]{2}{*}{ Variable } & \multicolumn{2}{|c|}{ Semi-Log Specification } & \multicolumn{2}{|c|}{ Log-Log Specification } \\
\hline & (1) & $(2)$ & $(3)$ & (4) \\
\hline $\ln \mathrm{MPK}_{j t}^{S}$ & $\begin{array}{c}0.102 \\
(0.016)\end{array}$ & - & $\begin{array}{c}0.576 \\
(0.075)\end{array}$ & - \\
\hline $\ln \mathrm{MPK}_{j t}^{\Pi}$ & - & $\begin{array}{c}0.094 \\
(0.018)\end{array}$ & - & $\begin{array}{c}0.547 \\
(0.081)\end{array}$ \\
\hline $\ln C_{j t}^{K}$ & $\begin{array}{l}-0.105 \\
(0.032)\end{array}$ & $\begin{array}{l}-0.076 \\
(0.031)\end{array}$ & $\begin{array}{l}-0.513 \\
(0.142)\end{array}$ & $\begin{array}{l}-0.400 \\
(0.137)\end{array}$ \\
\hline$[I / K]_{j, t-1}$ & $\begin{array}{c}0.311 \\
(0.039)\end{array}$ & $\begin{array}{c}0.342 \\
(0.037)\end{array}$ & $\begin{array}{c}0.450 \\
(0.035)\end{array}$ & $\begin{array}{c}0.472 \\
(0.035)\end{array}$ \\
\hline L-R Elasticity $^{a}$ & $\begin{array}{l}-0.970 \\
(0.286)\end{array}$ & $\begin{array}{l}-1.237 \\
(0.558)\end{array}$ & $\begin{array}{l}-1.122 \\
(0.294)\end{array}$ & $\begin{array}{l}-1.368 \\
(0.475)\end{array}$ \\
\hline $\operatorname{Pr}>\left|m_{1}\right|^{b}$ & 0.000 & 0.000 & 0.000 & 0.000 \\
\hline $\operatorname{Pr}>\left|m_{2}\right|^{c}$ & 0.540 & 0.393 & 0.693 & 0.458 \\
\hline $\operatorname{Pr}>J_{N}^{d}$ & 0.993 & 0.974 & 0.993 & 0.989 \\
\hline Panel Dimensions & & 3,876 & 2 & .0 \\
\hline
\end{tabular}

Notes: In columns 1 and 2 , the dependent variable is the real investment rate $[I / K]_{j t}$. In columns 3 and 4 , the dependent variable is the $\log$ of real investment rate $\ln [I / K]_{j t}$. All specifications time fixed effects $\left(\lambda_{t}\right)$ and firm fixed effects $\left(\mu_{j}\right)$, which are eliminated using the forward mean-differencing transformation. The resulting specification is estimated by GMM using a one-step weighting matrix; see Arellano [2003]. Heteroskedasticity- and autocorrelation-consistent asymptotic standard errors are reported in parentheses. Parameter estimate for $\ln \mathrm{MPK}^{\Pi}$ and the associated standard errors are adjusted for the fact that the $\log$ of $\mathrm{MPK}_{j t}^{\Pi}$ is computed as $\ln \left(0.5+\mathrm{MPK}_{j t}^{\Pi}\right)$.

${ }^{a}$ Estimate of the long-run elasticity of capital with respect to the user cost (see text for details). Standard errors are computed according to the delta method.

${ }^{b} p$-value for the test of the first-order serial correlation of the transformed residuals.

${ }^{c} p$-value for the test of the second-order serial correlation of the transformed residuals.

${ }^{d} p$-value for the Hansen [1982] test of the over-identifying restrictions. This test uses the minimized objective of the corresponding two-step GMM estimator.

imply long-run elasticities that are again close to unity. Relative to the two manufacturing sectors, the coefficient estimate on the user cost in the information sector is estimated with a substantial degree of imprecision. We suspect that the positive coefficient, as well as the imprecision of the estimate, reflect the difficulty of distinguishing capital goods prices from industry-level output prices in this sector.

Thus far, our results imply a significant effect of the user cost of capital on investment spending in both the short and the long run. According to our benchmark estimates, a 1 percentage point increase in the user cost leads to a decline in the rate of investment 
Table 6: Investment and the Cost of Capital

(Static Log-Log Sectoral Specification, 1987-2005)

\begin{tabular}{|c|c|c|c|c|c|}
\hline \multirow[b]{3}{*}{ Sector } & \multirow[b]{3}{*}{$O b s / N$} & \multicolumn{4}{|c|}{ Elasticity of Investment Demand } \\
\hline & & \multicolumn{2}{|c|}{ With respect to $\mathrm{MPK}^{\Pi}$} & \multicolumn{2}{|c|}{ With respect to $C^{K}$} \\
\hline & & Est. & $S t d E r r$ & Est. & StdErr \\
\hline Mining & $253 / 43$ & 0.469 & 0.113 & -0.249 & 0.109 \\
\hline Utilities & $542 / 74$ & 0.365 & 0.123 & -0.282 & 0.222 \\
\hline Construction & $40 / 7$ & 0.440 & 0.247 & -0.350 & 0.613 \\
\hline Mfg. (nondurable) & $1,781 / 212$ & 0.572 & 0.050 & -0.722 & 0.111 \\
\hline Mfg. (durable) & $1,649 / 222$ & 0.482 & 0.039 & -0.522 & 0.108 \\
\hline Wholesale Trade & $163 / 24$ & 0.915 & 0.211 & -1.143 & 0.465 \\
\hline Retail Trade & $528 / 70$ & 0.569 & 0.109 & -1.237 & 0.424 \\
\hline Transportation & $372 / 47$ & 0.458 & 0.172 & -0.588 & 0.149 \\
\hline Information & $662 / 118$ & 0.488 & 0.104 & 0.335 & 0.307 \\
\hline Services & $408 / 79$ & 0.646 & 0.105 & -0.616 & 0.371 \\
\hline
\end{tabular}

Notes: Dependent variable is $\ln [I / K]_{j t}$. The explanatory variables are $\ln \mathrm{MPK}_{j t}^{\Pi}$ and $\ln C_{j t}^{K}$. All specifications include firm fixed effects $\left(\mu_{j}\right)$ and time fixed effects $\left(\lambda_{t}\right)$ and are estimated by OLS. Heteroskedasticity- and autocorrelation-consistent asymptotic standard errors are computed according to Arellano [1987]. Parameter estimates for $\ln \mathrm{MPK}^{\Pi}$ and the associated standard errors are adjusted for the fact that the $\log$ of $\mathrm{MPK}_{j t}^{\Pi}$ is computed as $\ln \left(0.5+\mathrm{MPK}_{j t}^{\Pi}\right)$.

spending of 50 to 75 basis points. Because the after-tax interest rate is, on average, about two-thirds of the user cost, our estimates imply that a 1 percentage point increase in the real long-term interest rate induces a reduction in the rate of investment of 30 to 50 basis points in the short run. The elasticity of capital with respect to the user cost is equal to unity in the long run.

\section{Endogeneity of Interest Rates}

An important concern when estimating equation 4 is the potential endogeneity - reflecting both macroeconomic and firm-specific factors - between investment and the firm-specific interest rate used to construct the user cost of capital. The endogeneity at the macroeconomic level arises because long-term interest rates and the price of new investment goods typically fall during economic downturns when investment fundamentals are weak. If our proxies for investment fundamentals are subject to measurement error, the residual in the investment regression will capture the omitted factors - in this case, the residual is likely to be negatively correlated with the user cost. Macroeconomic considerations thus suggest that endogeneity between prices and quantities leads to a downward bias in the estimate of 
the elasticity of investment demand with respect to the user cost of capital. Using firm-level data, however, allows us to control for such biases by including time dummies to capture these macroeconomic co-movements.

The endogeneity at the firm level arises because variation in interest rates is due in part to the endogenous decisions made by firms when jointly determining their investment and financial policies. Such endogeneity leads to two types of biases. First, there is the potential for omitted variable bias owing to mismeasured fundamentals. Improvements in fundamentals are likely to increase investment, reduce the likelihood of future default, and, therefore, raise the price of the firm's outstanding bonds. Thus, with mismeasured fundamentals, corporate yields may fall while investment spending rises, a reflection of the endogenous response of interest rates and investment to unobservables. The presence of such endogeneity would imply an upward bias in the sensitivity of investment demand to the user cost of capital. Second, an increase in investment - everything else equal - may lead to higher leverage if firms finance a portion of their capital expenditures with external funds. The increased leverage would raise the likelihood of default, causing an increase in the yield on outstanding corporate debt. This bias, in contrast, would result in the estimated sensitivity of investment demand to the user cost of capital to be biased toward zero. In both cases, however, the endogenous response of interest rates is fully reflected in changes to the expected default risk.

In this section, we address this endogeneity issue in two specific ways. First, we construct an instrument for the cost of capital that is arguably exogenous to the firm's financial policy - that is, we compute the variation in interest rates that is orthogonal to the expected default risk and therefore exogenous to the firm's financial policy. Second, in order to control for omitted variable bias, we include additional explanatory variables in the investment regression.

\subsection{Investment and Default Risk}

Our measure of the probability that a firm will default within a certain period of time comes from the Moody's/KMV Corporation (MKMV). The theoretical underpinnings for these probabilities of default are provided by the seminal work of Merton [1973, 1974]. According to this option-theoretic approach, the probability that a firm will default on its debt obligations at any point in the future is determined by three major factors: the market value of the firm's assets, the standard deviation of the stochastic process for the market value of assets (i.e., asset volatility), and the firm's leverage. These three factors are combined into a single measure of default risk called distance to default.

In theory, the default point should equal the book value of total liabilities, implying that the distance to default compares the net worth of the firm with the size of a one-standard- 
deviation move in the firm's asset value. ${ }^{12}$ The market value of assets and the volatility of assets, however, are not directly observable, so they have to be computed in order to calculate the distance to default. Assuming that the firm's assets are traded, the market value of the firm's equity can be viewed as a call option on the firm's assets with the strike price equal to the current book value of the firm's total debt. ${ }^{13}$ Using this insight, MKMV "backs out" the market value and the volatility of assets from a proprietary variant of the Black-Scholes-Merton option pricing model, employing the observed book value of liabilities and the market value of equity as inputs; see Crosbie and Bohn [2003] for details.

In the final step, MKMV transforms the distance to default into an expected probability of default - the so-called expected default frequency (EDF) - using an empirical distribution of actual defaults. Specifically, MKMV estimates a mapping relating the likelihood of default over a particular horizon to various levels of distance to default, employing an extensive proprietary database of historical defaults and bankruptcies in the United States. ${ }^{14}$ These EDFs are calculated monthly and in our case measure the probability that a firm will default on its debt obligations over the subsequent 12 months. We used EDFs as of the last month of the firm's fiscal year when merging MKMV data to the annual Compustat data files. Because they are based primarily on equity valuations, EDF-based measures of default risk react rapidly to deterioration in the firm's credit quality and promptly reflect changes in aggregate economic conditions.

Using the information on firm-specific probabilities of default, we propose a methodology that identifies variation in firm-specific interest rates, and hence in the user cost of capital, that is orthogonal to default risk as well as macroeconomic risk factors that influence the price of such risk. According to standard asset pricing theory, the spread of corporate yields over yields on comparable maturity risk-free bonds - the credit spread-measures the compensation that holders of corporate bonds demand for the expected cost of default, which equals the expected default probability times the recovery rate (i.e., $\mathrm{EDF} \times R$ ). However, as pointed out by Elton, Gruber, Agrawal, and Mann [2001] and Huang and Huang [2003], the actual corporate credit spreads are considerably wider than can be explained by observed probabilities of default and historical recovery rates on the defaulted bonds. ${ }^{15}$

\footnotetext{
${ }^{12}$ Empirically, however, MKMV has found that most defaults occur when the market value of the firm's assets drops to the value equal to the sum of the firm's current liabilities and one-half of long-term liabilities (i.e., Default Point $=$ Current Liabilities $+0.5 \times$ Long-Term Liabilities), and the default point is calibrated accordingly.

${ }^{13}$ The assumption that all of the firm's assets are traded is clearly inappropriate in most cases. Nevertheless, as shown by Ericsson and Reneby [2004], this approach is still valid provided that at least one of the firm's securities (e.g., equity) is traded.

${ }^{14}$ The MKMV's mapping of distances to default to EDFs restricts the probability estimates to the range between 0.02 percent and 20 percent because of sparse data beyond these points. We omitted observations with EDFs at the boundary from our analysis.

${ }^{15}$ According to these studies, other most important constituents of credit spreads are tax and liquidity premiums. Relatedly, Collin-Dufresne, Goldstein, and Martin [2001] show that changes in credit spreads are
} 
Figure 3: Corporate Credit Spreads and Expected Default Frequencies

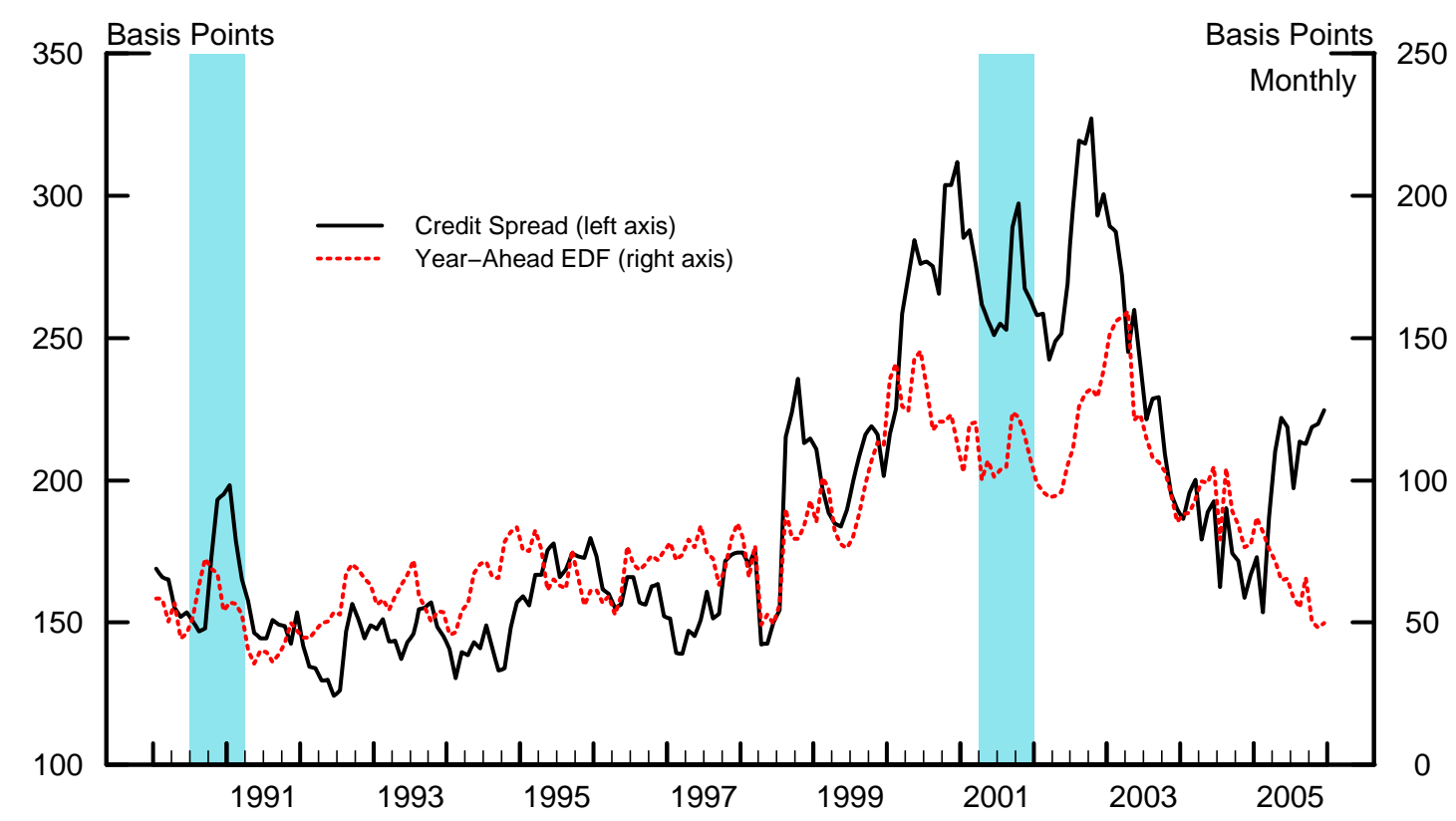

Notes: This figure depicts the time-series of the cross-sectional average credit spread - the solid line - and the cross-sectional average of the year-ahead expected default frequency (EDF) — dotted line - for the firms in our sample. The shaded vertical bars denote the NBER-dated recessions.

Indeed, this feature can be seen in Figure 3, which depicts the evolution of the average year-ahead EDF and the average credit spreads for the firms in our sample. Although this measure of expected default risk is, in general, highly correlated with the corporate credit spreads, during economic downturns or periods of heightened volatility in financial markets, spreads tend to increase considerably more than the likelihood of default.

To compute the variation in interest rates that is orthogonal to the expected default risk and therefore exogenous to the firm's financial policy, we follow Berndt, Douglas, Duffie, Ferguson, and Schranz [2005] and estimate a log-log specification of the form:

$$
\ln \left(r_{j t_{m}}-y_{t_{m}}\right)=c_{j t_{m}}+\theta \ln \mathrm{EDF}_{j t_{m}}+R_{j t_{m}}+f_{t_{m}}+u_{j t_{m}}
$$

where $r_{j t_{m}}$ denotes the portfolio yield on the firm $j$ 's outstanding bonds in month $t_{m}, y_{t_{m}}$ is the average yield on the Treasury securities of the same maturity, and $\mathrm{EDF}_{j t_{m}}$ denotes the year-ahead expected default frequency for firm $j$, measured at the beginning of the month $t_{m}$. To control for differences in recovery rates $R_{j t_{m}}$ and macro risk factors $f_{t_{m}}$, we include a full set of industry (3/4-digit NAICS) and time dummies in the regression equation $6 .^{16}$

influenced significantly by movements in macro risk factors and a time-varying liquidity premium.

${ }^{16}$ We also considered adding higher-order polynomial terms of $\ln \mathrm{EDF}_{j t_{m}}$ to the right-hand side of the 
We also augment our option-theoretic measures of expected default risk in equation 6 with default information from external ratings agencies. Because they are based mainly on movements in equity valuations, the EDFs incorporate high-frequency information regarding default risk. By contrast, external ratings of firms' senior unsecured debt contain low-frequency information that reflects a variety of firm and industry-specific factors not captured by the distance to default. In addition, credit ratings are based on a borrower's ability to meet its debt obligations in the event of an economic downturn and therefore contain information about the likelihood of default over a longer horizon (e.g., Löffler [2007]). Specifically, letting $n=1,2, \ldots, N$ index the $N$ distinct credit ratings (i.e., AAA, AA, A, etc.), we incorporate this additional information about the firm-specific likelihood of default by adding to the set of regressors a full set of dummy variables that measure the firm's rating of its senior unsecured debt. We do so by specifying that the firm-specific term $c_{j t_{m}}$ in equation 6 satisfies:

$$
c_{j t_{m}}=\sum_{n=1}^{N} \gamma_{n} 1\left(B_{j t_{m}}=n\right),
$$

where $1\left(B_{j t_{m}}=n\right)$ is the indicator function for firm $j$ 's credit rating $B_{j t_{m}}$ and the beginning of month $t_{m}$. The parameter $\gamma_{n}$, therefore, provides an estimate of the average credit spread for rating category $n=1,2, \ldots, N$ in month $t_{m}$, conditional on expected default.

The residual from the regression equation $6, u_{j t_{m}}$, is our measure of a firm-specific liquidity premium. ${ }^{17}$ The key requirement for $u_{j t_{m}}$ to be a valid instrument for the firmspecific user cost in the investment equation 5 is that these liquidity shocks are not correlated with the firm's investment opportunities. Note that $u_{j t_{m}}$ is, by construction, orthogonal to the expected default risk as measured by both the EDF and the firm's external credit rating. By employing as an instrument a variable that is orthogonal to the main source of potential endogeneity considered in the asset pricing literature - namely default risk - it seems quite reasonable to assume that these liquidity shocks are not determined by the firm's investment opportunities and, consequently, can be used to address the endogeneity between investment demand and the user cost of capital.

Because our investment data are on an annual basis, we construct our instrument-

regression equation 6 , because the relationship between corporate spreads and default risk, even in a log-log specification, may not be linear. However, the influence of these higher-order terms on the relationship between credit spreads and default risk was negligible, and all of our results were completely robust to this alternative specification.

${ }^{17}$ Berndt et al. [2005] use credit-default swap (CDS) data to determine the price of default risk by regressing the CDS spread on MKMV's expected default frequency. Blanco, Brennan, and Marsh [2005] argue that corporate bond prices suffer from liquidity premia owing to the limited supply of each firm's bonds at different maturities. Because credit-default swaps are derivatives, they are less likely to suffer from liquidity premia when traded in the secondary market. Indeed, Blanco et al. [2005] and use the gap between the bond price and the credit default swap - the so-called basis - as their measure of a liquidity premium, an approach consistent with our proposed methodology. 
that is, the average annual liquidity shock - as $\hat{u}_{j t}=\sum_{m=1}^{12} \hat{u}_{j t_{m}}$. These instruments are constructed to match each firm's fiscal year and thus reflect information within the fiscal year about fluctuations in firm-specific interest rates. As a result, they are correlated with the user cost of capital $C_{j t}^{K}$ and, according to our argument, uncorrelated with $\epsilon_{j t}$, the unobservable component of the investment demand equation. They may, therefore, be used as valid instruments to estimate the forward mean-differenced regression specified in equation 4. Formally, we are replacing the orthogonality condition $E\left[\epsilon_{j t} C_{j, t-k}^{K} \mid \mu_{j}, \lambda_{t}\right]=0$ with the orthogonality condition $E\left[\epsilon_{j t} \hat{u}_{j, t-k} \mid \mu_{j}, \lambda_{t}\right]=0$, for $k \geq 0$, which implies that current (and lagged) values of our liquidity shock $\hat{u}_{j t}$ are valid instruments for the forward mean-differenced error term $\Delta_{t}^{T_{j}}\left(\epsilon_{j t}\right)$. Because the MKMV data are only available from January 1991 onwards, our results are based on the 1991-2005 sub-period. We first report estimates of the yield spread regression 6 . Then we re-estimate the dynamic specification reported in Table 5 for the 1991-2005 period using liquidity shocks as instruments.

Table 7 reports the regression results from estimating the yield spread equation 6 . We consider four separate specifications. The first specification only includes the log of the expected default frequency. We then augment this baseline specification sequentially with industry fixed effects, time fixed effects, and credit-rating variables. As noted in the first column, the EDF term alone yields an $R^{2}$ of 0.483 , a goodness-of-fit similar to that reported by Berndt et al. [2005] who used credit default swap spreads in place of spreads on outstanding corporate bonds. Although industry fixed effects do not appear to have a large impact, the addition of the time dummies - included to capture variation in macro risk factors - significantly improves the fit of the regression and implies a modest reduction in the coefficient on the EDF. Finally, the inclusion of credit-rating dummies substantially reduces the effect of the expected default frequency and significantly raises the explanatory power of the regression. With all four factors included, the regression explains almost 76 percent of the monthly variation in the corporate credit spreads.

Figure 4 displays the impact of the credit-rating indicators on yield spreads from specification 4 in Table $7{ }^{18}$ As expected, these estimates imply a strong negative relationship between external credit ratings and corporate yield spreads. Our estimates imply a differential in yield spreads between C-rated and AAA-rated firms of more than 200 basis points, on average, with most of this difference occurring between the CCC1 and AA3 rating categories.

We now consider the effect of instrumenting the user cost of capital with our estimates of

\footnotetext{
${ }^{18}$ Because the dependent variable is in logs, the impact of the credit rating $n$ on the level of yield spreads is given by $\exp \left(\hat{\gamma}_{n}-V\left(\hat{\gamma}_{n}\right)\right)-1$, where $\hat{\gamma}_{n}$ is the estimated coefficient on a dummy variable associated with rating $n$ and $V\left(\hat{\gamma}_{n}\right)$ is the estimated variance of $\hat{\gamma}_{n}$ (cf., Kennedy [1981]. In addition, we restricted the sum of coefficients on each set of dummy variables (i.e., industry, time, and credit rating) to sum to zero. The estimated coefficients in Figure 4 thus measure the effect of each credit rating relative to the average rating effect.
} 
Table 7: Credit Spreads and Default Risk

\begin{tabular}{|c|c|c|c|c|}
\hline \multirow[b]{2}{*}{ Variable } & \multicolumn{4}{|c|}{ Specification } \\
\hline & (1) & $(2)$ & $(3)$ & (4) \\
\hline \multirow[t]{2}{*}{ Constant } & 3.662 & 3.737 & 4.207 & 5.776 \\
\hline & $(0.028)$ & $(0.084)$ & $(0.091)$ & $(0.088)$ \\
\hline \multirow{2}{*}{$\ln \mathrm{EDF}_{j, t-1}$} & 0.393 & 0.386 & 0.359 & 0.119 \\
\hline & $(0.007)$ & $(0.007)$ & $(0.008)$ & $(0.007)$ \\
\hline \multirow[t]{2}{*}{ Industry Effects $^{a}$} & no & yes & yes & yes \\
\hline & & $(0.000)$ & $(0.000)$ & $(0.000)$ \\
\hline \multirow[t]{2}{*}{ Time Effects ${ }^{b}$} & no & no & yes & yes \\
\hline & & & $(0.000)$ & $(0.000)$ \\
\hline \multirow[t]{2}{*}{ Ratings Effects $^{c}$} & no & no & no & yes \\
\hline & & & & $(0.000)$ \\
\hline$R^{2}$ & 0.483 & 0.509 & 0.576 & 0.755 \\
\hline $\mathrm{BIC}^{d}$ & 94.83 & 92.36 & 85.95 & 54.25 \\
\hline Panel Dimensions & Obs $=$ & 8,037 & $N=872$ & $\bar{T}=66.6$ \\
\hline
\end{tabular}

Notes: Estimation period: Monthly data from February 1991 to December 2005. Dependent variable is the $\log$ of the credit spread $\ln \left(r_{j t}-y_{j t}\right)$. All specifications are estimated by OLS. Heteroskedasticity- and autocorrelationconsistent asymptotic standard errors are reported in parentheses.

${ }^{a} p$-values for the test of the null hypothesis of the absence of industry fixed effects are reported in parentheses.

${ }^{b} p$-values for the test of the null hypothesis of the absence of time fixed effects are reported in parentheses.

${ }^{c} p$-values for the test of the null hypothesis of the absence of credit-rating fixed effects (as of the beginning-of-period $t$ ) are reported in parentheses.

${ }^{d}$ Schwarz Bayesian Information Criterion (smaller is better).

liquidity shocks. We focus on the dynamic specification that uses forward mean-differencing to eliminate the firm fixed effect $\mu_{j}$. The forward mean-differencing allows us to instrument the user cost without imposing the additional assumption that the current error term in the investment equation is orthogonal to future information that may be reflected in the bond market through liquidity shocks. Table 8 reports results for this dynamic specification estimated over the 1991-2005 sample period.

Remarkably, using the liquidity shock as an instrument causes the coefficient on the user cost to increase in magnitude for three out of the four specifications reported in Table 8. The coefficient is essentially unchanged for the log-log specification that uses $\mathrm{MPK}_{j t}^{\Pi}$ to measure the marginal product of capital. Although differences in the estimates reported in Tables 5 and 8 are not statistically significant, our instrumental variable results imply 
Figure 4: The Effect of Ratings on Credit Spreads

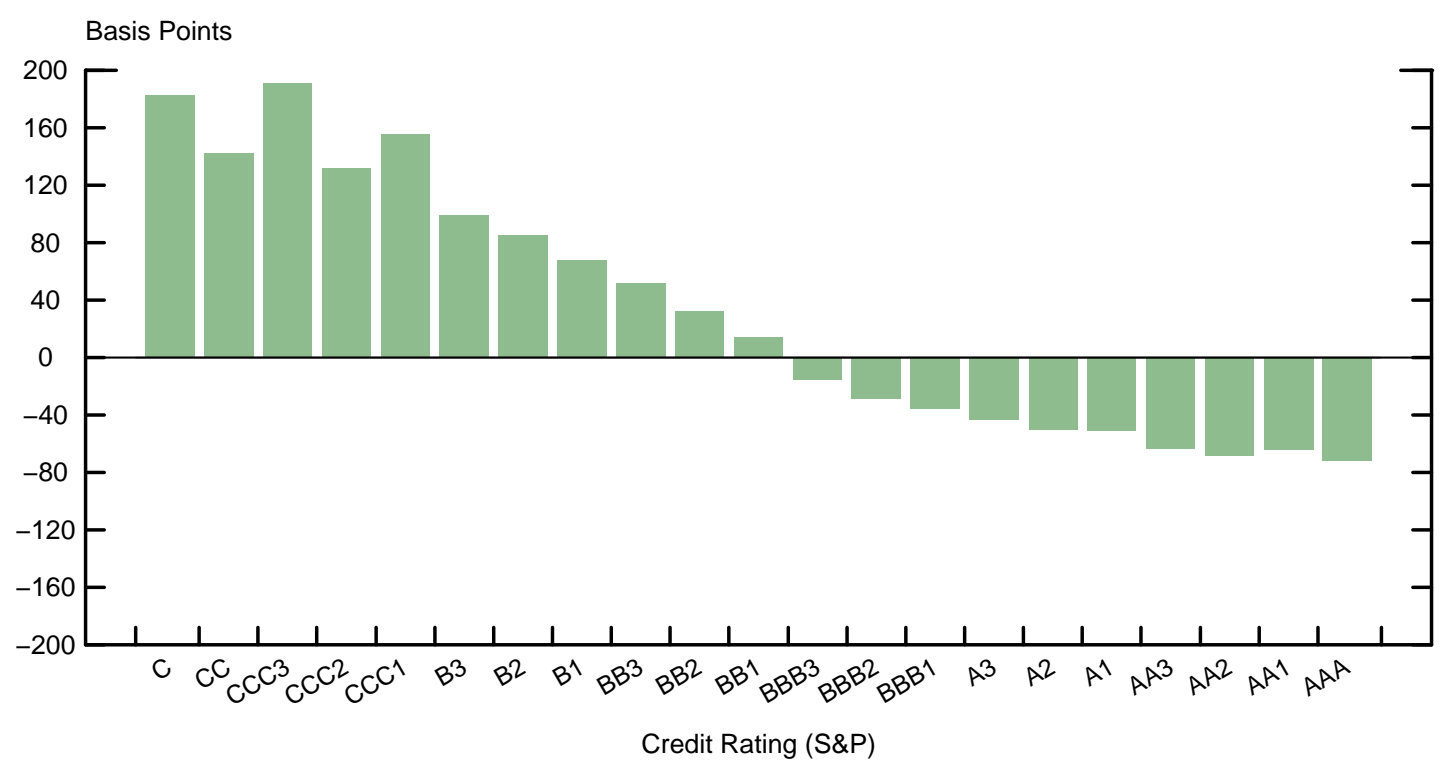

Notes: This figure depicts the estimated effect of external credit ratings on corporate yield spreads from specification 4 in Table 7 . The rating effects shown are measured relative to the average rating effect (see text for details).

that our benchmark estimates of the user-cost effect are unlikely to be biased to the upside because of the endogeneity between interest rates and the firm's financial policy. The higher estimated coefficient on the user cost also reduces somewhat our estimate of the long-run elasticity of capital. In none of these cases, however, can we reject the hypothesis that the long-run elasticity of capital with respect to the user cost is unity.

\subsection{Investment, the Cost of Capital, and Other Factors}

An alternative to the instrumental variables approach discussed above is to include additional explanatory variables - which capture the potentially omitted information - in the regression. The variables we consider are Tobin's Q and expected default risk as measured by EDFs. Because both Tobin's Q and EDFs are based on stock market data, they are forward-looking variables and, consequently, may contain information about future investment opportunities not captured by our current measures of the marginal product of capital. Thus, including Tobin's Q and EDFs in the regression provides another way to address the potential endogeneity between interest rates, investment opportunities, and financial policy that motivated our original instrumental variables procedure.

Because the investment data are annual, we augment the regression with the EDF and Tobin's Q constructed using the information as of the beginning of the period; the 
Table 8: Investment, Cost of Capital, and Liquidity Shocks (Dynamic Specification, 1991-2005)

\begin{tabular}{|c|c|c|c|c|}
\hline \multirow[b]{2}{*}{ Variable } & \multicolumn{2}{|c|}{ Semi-Log Specification } & \multicolumn{2}{|c|}{ Log-Log Specification } \\
\hline & (1) & $(2)$ & $(3)$ & (4) \\
\hline $\ln \mathrm{MPK}_{j t}^{S}$ & $\begin{array}{c}0.153 \\
(0.025)\end{array}$ & - & $\begin{array}{c}0.671 \\
(0.126)\end{array}$ & - \\
\hline $\ln \mathrm{MPK}_{j t}^{\Pi}$ & - & $\begin{array}{c}0.132 \\
(0.022)\end{array}$ & - & $\begin{array}{c}0.432 \\
(0.111)\end{array}$ \\
\hline $\ln C_{j t}^{K}$ & $\begin{array}{l}-0.204 \\
(0.054)\end{array}$ & $\begin{array}{l}-0.148 \\
(0.046)\end{array}$ & $\begin{array}{l}-0.749 \\
(0.226)\end{array}$ & $\begin{array}{l}-0.405 \\
(0.180)\end{array}$ \\
\hline$[I / K]_{j, t-1}$ & $\begin{array}{c}0.276 \\
(0.051)\end{array}$ & $\begin{array}{c}0.329 \\
(0.050)\end{array}$ & $\begin{array}{c}0.439 \\
(0.043)\end{array}$ & $\begin{array}{c}0.444 \\
(0.048)\end{array}$ \\
\hline L-R Elasticity $^{a}$ & $\begin{array}{l}-0.747 \\
(0.193)\end{array}$ & $\begin{array}{l}-0.890 \\
(0.302)\end{array}$ & $\begin{array}{l}-0.895 \\
(0.209)\end{array}$ & $\begin{array}{l}-1.065 \\
(0.433)\end{array}$ \\
\hline $\operatorname{Pr}>\left|m_{1}\right|^{b}$ & 0.000 & 0.000 & 0.000 & 0.000 \\
\hline $\operatorname{Pr}>\left|m_{2}\right|^{c}$ & 0.663 & 0.402 & 0.867 & 0.666 \\
\hline $\operatorname{Pr}>J_{N} d$ & 1.000 & 1.000 & 1.000 & 0.992 \\
\hline Panel Dimensions & & 3,076 & 581 & 5.3 \\
\hline
\end{tabular}

Notes: In columns 1 and 2 , the dependent variable is the real investment rate $[I / K]_{j t}$. In columns 3 and 4 , the dependent variable is the log of real investment rate $\ln [I / K]_{j t}$. All specifications time fixed effects $\left(\lambda_{t}\right)$ and firm fixed effects $\left(\mu_{j}\right)$, which are eliminated using the forward mean-differencing transformation. The resulting specification is estimated by GMM using a one-step weighting matrix; see Arellano [2003]. Heteroskedasticity- and autocorrelation-consistent asymptotic standard errors are reported in parentheses. Parameter estimate for $\ln \mathrm{MPK}^{\Pi}$ and the associated standard errors are adjusted for the fact that the $\log$ of $\mathrm{MPK}_{j t}^{\Pi}$ is computed as $\ln \left(0.5+\mathrm{MPK}_{j t}^{\Pi}\right)$.

${ }^{a}$ Estimate of the long-run elasticity of capital with respect to the user cost (see text for details). Standard errors are computed according to the delta method.

${ }^{b} p$-value for the test of the first-order serial correlation of the transformed residuals.

${ }^{c} p$-value for the test of the second-order serial correlation of the transformed residuals.

${ }^{d} p$-value for the Hansen [1982] test of the over-identifying restrictions. This test uses the minimized objective of the corresponding two-step GMM estimator.

EDF thus measures the likelihood of default over the coming year. This contrasts with our instrumental variables procedure, which allowed us to exploit the relationship between credit spreads and expected default risk at a monthly frequency, thus yielding an instrument that was constructed using information in the fiscal year in which the investment was made. Because the two approaches rely on a different information structure, each should be informative regarding potential biases in our regression analysis. ${ }^{19}$

\footnotetext{
${ }^{19}$ Recall that when using liquidity shocks as instruments, we restricted our analysis to the forward meandifferenced specification to ensure that our instrument was truly orthogonal to the transformed error term,
} 
Table 9: Investment, the Cost of Capital, and Other Factors (Static Specification, 1991-2005)

\begin{tabular}{|c|c|c|c|c|c|}
\hline \multirow[b]{2}{*}{ Variable } & \multicolumn{5}{|c|}{ Semi-Log Specification } \\
\hline & (1) & $(2)$ & $(3)$ & (4) & $(5)$ \\
\hline $\ln \mathrm{MPK}_{j t}^{\Pi}$ & $\begin{array}{c}0.100 \\
(0.007)\end{array}$ & $\begin{array}{c}0.080 \\
(0.010)\end{array}$ & $\begin{array}{c}0.089 \\
(0.011)\end{array}$ & $\begin{array}{c}0.093 \\
(0.009)\end{array}$ & $\begin{array}{c}0.086 \\
(0.011)\end{array}$ \\
\hline $\ln C_{j t}^{K}$ & $\begin{array}{l}-0.077 \\
(0.018)\end{array}$ & $\begin{array}{l}-0.064 \\
(0.018)\end{array}$ & $\begin{array}{l}-0.075 \\
(0.023)\end{array}$ & $\begin{array}{l}-0.064 \\
(0.020)\end{array}$ & $\begin{array}{l}-0.066 \\
(0.023)\end{array}$ \\
\hline $\ln Q_{j t}^{A V G}$ & - & $\begin{array}{c}0.091 \\
(0.012)\end{array}$ & - & - & - \\
\hline $\ln Q_{j t}^{K M V}$ & - & - & $\begin{array}{c}0.064 \\
(0.010)\end{array}$ & & $\begin{array}{c}0.046 \\
(0.011)\end{array}$ \\
\hline $\ln \mathrm{EDF}_{j, t-1}$ & - & - & - & $\begin{array}{l}-0.015 \\
(0.002)\end{array}$ & $\begin{array}{l}-0.010 \\
(0.003)\end{array}$ \\
\hline \multirow[t]{2}{*}{$R^{2}$ (within) } & 0.247 & 0.294 & 0.310 & 0.287 & 0.317 \\
\hline & \multicolumn{5}{|c|}{ Log-Log Specification } \\
\hline Variable & (1) & $(2)$ & $(3)$ & (4) & (5) \\
\hline $\ln \mathrm{MPK}_{j t}^{\Pi}$ & $\begin{array}{c}0.539 \\
(0.036)\end{array}$ & $\begin{array}{c}0.440 \\
(0.042)\end{array}$ & $\begin{array}{c}0.460 \\
(0.048)\end{array}$ & $\begin{array}{c}0.500 \\
(0.041)\end{array}$ & $\begin{array}{c}0.442 \\
(0.048)\end{array}$ \\
\hline $\ln C_{j t}^{K}$ & $\begin{array}{l}-0.511 \\
(0.093)\end{array}$ & $\begin{array}{l}-0.464 \\
(0.092)\end{array}$ & $\begin{array}{l}-0.479 \\
(0.121)\end{array}$ & $\begin{array}{l}-0.450 \\
(0.102)\end{array}$ & $\begin{array}{l}-0.417 \\
(0.121)\end{array}$ \\
\hline $\ln Q_{j t}^{A V G}$ & - & $\begin{array}{c}0.491 \\
(0.056)\end{array}$ & - & - & - \\
\hline $\ln Q_{j t}^{K M V}$ & - & - & $\begin{array}{c}0.368 \\
(0.051)\end{array}$ & & $\begin{array}{c}0.246 \\
(0.059)\end{array}$ \\
\hline $\ln \mathrm{EDF}_{j, t-1}$ & - & - & - & $\begin{array}{l}-0.096 \\
(0.014) \\
\end{array}$ & $\begin{array}{l}-0.069 \\
(0.017) \\
\end{array}$ \\
\hline$R^{2}$ (within) & 0.268 & 0.311 & 0.324 & 0.305 & 0.335 \\
\hline
\end{tabular}

Notes: In the semi-log specifications, the dependent variable is the real investment rate $[I / K]_{j t}$. In the log-log specifications, the dependent variable is the $\log$ of real investment rate $\ln [I / K]_{j t}$. All specifications include firm fixed effects $\left(\mu_{j}\right)$ and time fixed effects $\left(\lambda_{t}\right)$ and are estimated by OLS. Heteroskedasticity- and autocorrelation-consistent asymptotic standard errors are computed according to Arellano [1987] and are reported in parentheses. Parameter estimate for $\ln \mathrm{MPK}^{\Pi}$ and the associated standard errors are adjusted for the fact that the log of $\mathrm{MPK}_{j t}^{\Pi}$ is computed as $\ln \left(0.5+\mathrm{MPK}_{j t}^{\Pi}\right)$.

In the regression that includes Tobin's Q, we consider two alternative ways to measure Q.

given that liquidity shocks use contemporaneous information. In the augmented regression, by contrast, we use beginning-of-period values of Tobin's Q and the EDF, and we are, therefore, less concerned about 
The first measure - denoted by $Q^{A V G}$ — uses the sum of the market value of the firm's equity and the book value of its debt, divided by the replacement value of capital. The numerator in the second measure - denoted by $Q^{K M V}$ - is equal to the market value of the firm calculated by MKMV using the Merton model discussed above. To our knowledge, we are first to use this measure of Tobin's $\mathrm{Q}$ in an investment regression. ${ }^{20}$

Estimation results from this exercise are reported in Table 9. Because EDFs are only available from January 1991 onwards, we again restrict our attention to the 1991-2005 period. The top panel of the table reports estimates using the semi-log specification, whereas the bottom panel reports estimates using the log-log specification. According to the entries in the table, Tobin's Q adds explanatory power to the regression, with point estimates that are highly statistically significant and of the magnitude consistent with previous studies. Importantly, the addition of the Tobin's $\mathrm{Q}$ to the regression has very little effect on the parameter estimates associated with the user cost and the marginal product of capital, regardless of the measure of Tobin's Q used.

The expected default frequency also adds explanatory power to the investment regression. The coefficient on the EDF is statistically significant but economically unimportantgiven an average default rate of 1 percent and an average investment rate of 18 percent, a 1 percentage point increase in expected default implies a reduction in the rate of investment of just 2 basis points. Whereas the beginning-of-period expected default risk does provide independent information relative to the user cost, the parameter estimate on the user cost is unaffected by the inclusion of the EDF variable. The results in Table 9 thus provide further evidence against the possibility that our benchmark estimates of the user-cost effect are biased, owing to either omitted variable bias or endogeneity issues related to the joint determination of the firm's investment and financial policy.

\section{Conclusion}

In this paper, we employed a newly constructed data set linking firm-specific bond prices and default probabilities to balance sheet and income statement data in order to study the effect of variation in interest rates on investment spending. The bond price data, based on

bias arising from contemporaneous correlation. Our results, however, are unchanged if we use a forward mean-differenced transformation and/or allow for a lagged dependent variable.

${ }^{20}$ Given the theoretical and empirical attention lavished on investment-Q regressions, it is also of independent interest to determine whether $\mathrm{Q}$ has explanatory power for investment once one controls for the user cost, or, put differently, whether the user cost matters, conditional on Q. From a theoretical perspective, asset markets, under constant returns to scale, should fully price the effect of firm-specific interest rates on investment. Thus, the user cost should matter only to the extent that it serves as a tax-adjustment for Q. The primary source of cross-sectional heterogeneity in our measure of the user cost comes from interest rates, as variation in the tax term is not firm specific. Including both the user cost and Tobin's Q, therefore, provides further information on the extent to which $Q$ serves as a sufficient statistic for investment. 
trades in the secondary market, allowed us to use a firm-specific measure of the marginal cost of external finance to construct the user cost of capital. In contrast to a large number of previous studies that have documented little, if any, systematic relationship between the cost of capital and investment spending, our results imply a robust and quantitatively important effect of the user cost on investment at the firm level. According to our benchmark estimates, a 1 percentage point increase in the user cost of capital implies a reduction in the rate of investment of 50 to 75 basis points and, in the long run, a 1 percent reduction in the stock of capital.

Given the substantial variation in financing costs observed both over time and across firms, our results bring renewed interest to questions regarding the determination of capital costs and their effect on investment spending. In particular, our results suggest that, in the absence of countervailing forces, the sharp widening in corporate yield spreads and the associated rise in default risk experienced by the corporate sector during 2001-02 period likely exerted a significant drag on investment spending during the most recent economic downturn. 


\section{References}

Abel, A. B., and O. J. Blanchard (1986): "The Present Value of Profits and Cyclical Movements in Investment," Econometrica, 54, 249-273.

Arellano, M. (1987): "Computing Robust Standard Errors for Within-Group Estimators," Oxford Bulletin of Economics and Statistics, 49, 431-434.

_ (2003): Panel Data Econometrics. Oxford University Press, Oxford, UK.

Auerbach, A. J. (1983): "Taxation, Corporate Financial Policy, and the Cost of Capital," Journal of Economic Literature, 21, 905-940.

Bernanke, B. S., H. Bohn, and P. Reiss (1988): "Alternative Non-Nested Specification Tests of Time Series Investment Models," Journal of Econometrics, 37, 293-326.

Berndt, A., R. Douglas, D. Duffie, M. Ferguson, and D. Schranz (2005): "Measuring Default Risk Premia From Default Swap Rates and EDFs," Mimeo, Tepper School of Business, Carnegie Mellon University.

Blanco, R., S. Brennan, and I. W. Marsh (2005): "An Empirical Analysis of the Dynamic Relation between Investment-Grade Bonds and Credit Default Swaps," Journal of Finance, 60, 2255-2281.

Caballero, R. J. (1994): "Small Sample Bias and Adjustment Costs," Review of Economics and Statistics, 76, 52-58.

Chirinko, R. S. (1993): "Business Fixed Investment Spending: A Critical Survey of Modeling Strategies, Empirical Results, and Policy Implications," Journal of Economic Literature, 31, 1875-1911.

Chirinko, R. S., S. M. Fazzari, and A. P. Meyer (1999): "How Responsive is Business Capital to User Cost? An Exploration with Micro Data," Journal of Public Economics, $74,53-80$.

(2004): "That Elusive Elasticity: A Long-Panel Approach to Estimating the Capital-Labor Substitution Elasticity," Working Paper Washington University in St. Louis.

Collin-Dufresne, P., R. S. Goldstein, and J. S. Martin (2001): "The Determinants of Credit Spread Changes," Journal of Finance, 56, 2177-2207.

Crosbie, P. J., And J. R. Bohn (2003): "Modeling Default Risk," Research Report, Moody's $\mid \mathrm{K} \cdot \mathrm{M} \cdot \mathrm{V}$ Corporation.

Cummins, J. G., K. A. Hassett, and R. G. Hubbard (1994): "A Reconsideration of Investment Behavior Using Tax Reforms as Natural Experiments," Brookings Papers on Economic Activity, 2, 1-59.

DE Boor, C. (1981): A Practical Guide to Splines. Springer-Verlag, New York. 
Devereux, M., M. J. Keen, and F. Schiantarelli (1994): "Corporate Tax, Investment, and the Role of Tax Asymmetries," Journal of Public Economics, 53, 395-418.

Eisner, R., And I. M. NAdiRi (1968): "Investment Behavior and Neoclassical Theory," Review of Economics and Statistics, 50, 369-382.

Elton, E. J., M. J. Gruber, D. Agrawal, and C. Mann (2001): "Explaining the Rate Spread on Corporate Bonds," Journal of Finance, 56, 247-277.

Ericsson, J., and J. Reneby (2004): "A Note on Contingent Claims Pricing with NonTraded Assets," Finance Letters, 2, No. 3.

Gilchrist, S., and C. P. Himmelberg (1998): "Investment: Fundamentals and Finance," in NBER Macro Annual, ed. by B. S. Bernanke, and J. J. Rotemberg, pp. 223-274. The MIT Press, Cambridge.

Guiso, L., A. K. Kashyap, F. Panetta, and D. Terlizzese (2002): "How Interest Sensitive is Investment? Very (when the data are well measured)," Working Paper, University of Chicago Graduate School of Business.

Gürkaynak, R. S., B. Sack, and J. H. Wright (2006): "The U.S. Treasury Yield Curve: 1961 to the Present," Finance and Economics Discussion Series Paper No. 28, Federal Reserve Board.

Hall, R. E., And D. W. Jorgenson (1967): "Tax Policy and Investment Behavior," American Economic Review, 57, 319-414.

Hansen, L. P. (1982): "Large Sample Properties of Generalized Method of Moment Estimators," Econometrica, 50, 1029-1054.

Hassett, K. A., And R. G. Hubbard (1997): "Tax Policy and Investment," in Fiscal Policy: Lessons from Economic Research, ed. by A. J. Auerbach, pp. 339-385. MIT Press, Cambridge.

House, C. L., And M. D. Shapiro (2006): "Phased-In Tax Cuts and Economic Activity," Forthcoming American Economic Review.

Huang, J.-Z., And M. Huang (2003): "How Much of the Corporate-Treasury Yield Spread is Due to Credit Risk?: A New Calibration Approach," Working Paper, Pennsylvania State University.

Kennedy, P. (1981): "Estimation with Correctly Interpreted Dummy Variables in Semilogarithmic Equations," American Economic Review, 71, 801.

LÖffler, G. (2007): "The Complementary Nature of Ratings and Market-Based Measures of Default Risk," Forthcoming, Journal of Fixed Income.

Merton, R. C. (1973): "A Rational Theory of Option Pricing," Bell Journal of Economics and Management Science, 4, 141-183. 
(1974): "On the Pricing of Corporate Debt: The Risk Structure of Interest Rates," Journal of Finance, 29, 449-470.

Oliner, S. D., G. Rudebusch, and D. E. Sichel (1995): "New and Old Models of Business Investment: A Comparison of Forecasting Performance," Journal of Money, Credit, and Banking, 27, 804-826.

Philippon, T. (2007): "The $y$-Theory of Investment," Working Paper, Stern School of Business, New York University.

Salinger, M. A., And L. H. Summers (1983): "Tax Reform and Corporate Investment: A Microeconomic Simulation Study," in Behavioral Simulation Methods in Tax Policy Analysis, ed. by M. S. Feldstein, pp. 247-287. The University of Chicago Press, Chicago.

Schaller, H. (2006): "Estimating the Long-Run User Cost Elasticity," Journal of Monetary Economics, 53, 725-736.

Shapiro, M. D. (1986): "The Dynamic Demand for Capital and Labor," Quarterly Journal of Economics, 101, 513-542.

Tevlin, S., And K. Whelan (2003): "Explaining the Investment Boom of the 1990s," Journal of Money, Credit, and Banking, 35, 1-22.

Warga, A. D. (1991): “A Fixed Income Database," Mimeo, University of Houston. 


\section{Appendices}

\section{A Components of the User Cost of Capital}

This appendix describe the construction of the industry-specific components of the user cost of capital. Unless otherwise noted, the underlying industry-level data come from the Bureau of Economic Analysis (BEA) and are available at the annual frequency from 1987 to 2005. Following the BEA, our industry classification encompasses 52 industries based on the 3-digit (in some cases 4-digit) North American Industrial Classification System (NAICS).

Price of New Investment, Capital, and Output: The annual data on the price of new investment and the price of existing capital stock come from the BEA's Detailed Fixed Assets Tables. Using the chain-type quantity indexes and the historical-cost investment in, and holdings of, private fixed assets - that is, equipment and software, and structures - we derived an implicit price deflator for investment goods $\left(P_{s t}^{I}\right)$ and an implicit price deflator for the existing capital stock $\left(P_{s t}^{K}\right)$ for all 52 industries. Chain-type price indexes for gross output for the same set of industries $\left(P_{s t}^{Y}\right)$ come from the BEA's Gross-Domestic-Productby-Industry Accounts. The base year for all indexes in 2000. Because firms in our sample have fiscal years ending in different months of the year, we interpolated the annual price indexes to monthly frequency using cubic splines. ${ }^{21}$ The resulting industry-level monthly price indexes were averaged over the 12 relevant months of each firm's fiscal year and merged with the annual firm-level data.

To construct expected capital gains (or losses) stemming from the firm's purchase of capital goods $\left(E_{t}\left[\Delta P_{s, t+1}^{I} / P_{s t}^{I}\right]\right)$, we employed a simplifying assumption that any expected capital gains in year $t$ are equal to the five-year moving average of the realized capital goods inflation - as measured by the industry-specific price deflator for new investment goods $P_{s t}^{I}$-from year $t-1$ :

$$
E_{t}\left[\frac{\Delta P_{s, t+1}^{I}}{P_{s t}^{I}}\right]=\frac{1}{5} \sum_{k=1}^{5} \ln \left(\frac{P_{s, t-k-1}^{I}}{P_{s, t-k-2}^{I}}\right) .
$$

We experimented with a number of other adaptive schemes to create a proxy for expected capital gains - including setting it equal to zero - and all of our results were robust to these alternative assumptions.

Depreciation: To construct depreciation rates, we used annual estimates of net stocks and depreciation by NAICS industry for private nonresidential fixed assets available in the Detailed Fixed Assets Tables. The time-varying depreciation rate for industry $s$ was constructed as

$$
\delta_{s t}=\frac{D_{s t}}{K_{s, t-1}}
$$

\footnotetext{
${ }^{21}$ See, for example, de Boor [1981]. We also took logs of all industry-level series prior to the interpolation; the logs of price indexes at the monthly frequency were then exponentiated to obtain monthly levels of price indexes at the industry level.
} 
where $D_{s t}$ is the real dollar value of depreciation of private fixed assets in industry $s$ during year $t$ and $K_{s, t-1}$ is the real stock of capital in industry $s$ at the end of year $t-1$. As with the price indexes, we interpolated the annual industry-specific depreciation rates to monthly frequency using cubic splines, and the resulting monthly data were then averaged over the 12 relevant months of each firm's fiscal year and merged with the annual firm-level data. $^{22}$

Tax Considerations: Our source of the tax-related data is the Federal Reserve's FRB/US quarterly macroeconometric model of the U.S. economy. The FRB/US model separates business fixed investment into three categories of investment spending: high-tech equipment, other business equipment, and business structures. For each of these investment categories, the FRB/US model contains a detailed modeling of the tax code for depreciation allowances, tax service lives, and investment tax credits. Our sample period (1987-2005), however, is marked by a relatively stable corporate tax environment. For example, the marginal tax rate on corporate profits $\left(\tau_{t}\right)$, which we assume to be common across firms, was 34 percent between 1987:Q1 and 1992:Q4 and 35 percent for the remainder of our sample period. The Tax Reform Act of 1986 eliminated the investment tax credit on most assets (the ITC term in the user cost formula) and, with the exception of the Job Creation and Worker Assistance Act of 2002, the patterns of depreciation used to calculate the present discounted (PDV) value of depreciation deductions are relatively straightforward.

To construct the PDV of depreciation allowances $\left(z_{t}\right)$ at the industry level, we combined the BEA's investment data with the FRB/US tax-related series. Specifically, the FRB/US model contains expressions for the PDV of depreciation allowances for high-tech equipment $\left(z_{t}^{H T}\right)$, other business equipment $\left(z_{t}^{O T H}\right)$, and nonresidential structures $\left(z_{t}^{N R S}\right)$, based on continuous time formulas for allowable depreciation methods. Specifically, letting $L$ denote a lifetime of the asset for tax purposes, then the PDV of deductions for a one dollar purchase is given by

$$
z=\frac{B}{L} \int_{0}^{l^{*}} e^{-(i+B / L) t} d t+\left(\frac{e^{-(B / L) l^{*}}}{L}\right) \int_{l^{*}}^{L} e^{-i t} d t,
$$

where $B$ is the declining balance used in the accelerated depreciation method (e.g., in case of a double declining balance pattern $B=2$ ), $i$ is the nominal interest rate, and $0<l^{*}<L$ is the optimal switchover time from the accelerated depreciation to the straightline method. ${ }^{23}$ We set the nominal interest rate $i$ equal to 7 percent when calculating the PDV of depreciation allowances. The expressions in the FRB/US also take into account temporary increases in depreciation allowances for spending on equipment and software (E\&S) that were passed in 2002 and $2003 .^{24}$

\footnotetext{
${ }^{22}$ Prior to the interpolation, we applied the logit transformation to annual depreciation rates, and the resulting interpolated series were then transformed back using the inverse logit transformation. This transformation of the data ensured that the interpolated monthly depreciation rates remained in the $(0,1)$ interval.

${ }^{23}$ Under accelerated depreciation, firms can never deduct the full nominal value of their purchase, so the tax code allows a switch to the straight-line method to complete the depreciation write-off. For high-tech and other business equipment categories of investment spending, these formulas take into account the optimal switchover point from accelerated depreciation methods to the straight line pattern of depreciation-for nonresidential structures, by contrast, the Tax Reform Act of 1986 stipulates only the straight-line method.

${ }^{24}$ The Job Creation and Worker Assistance Act of 2002 included a temporary increase in depreciation
} 
In the next step, we interpolated our estimates of $z_{t}^{H T}, z_{t}^{O T H}$, and $z_{t}^{N R S}$ from quarterly to monthly frequency using cubic splines. ${ }^{25}$ From the BEA's Detailed Fixed Assets Tables, we then calculated annual (nominal) investment expenditures for the corresponding investment categories - denoted by $I_{t}^{H T}, I_{t}^{O T H}$, and $I_{t}^{N R S}$, respectively - and interpolated them to monthly frequency using the same methodology as in the case of price indexes. We then constructed the present value of depreciation allowances for investment in $E \& S$ as

$$
z_{t}^{E S}=\left[\frac{I_{t}^{H T}}{I_{t}^{E S}}\right] \times z_{t}^{H T}+\left[\frac{I_{t}^{O T H}}{I_{t}^{E S}}\right] \times z_{t}^{O T H}
$$

where $I_{t}^{E S}=I_{t}^{H T}+I_{t}^{\text {Отн }}$ denotes aggregate (nominal) investment in E\&S, interpolated to monthly frequency using the same method. Using (nominal) investment in E\&S and nonresidential structures by industry - denoted by $I_{s t}^{E S}$ and $I_{s t}^{N R S}$, respectively - we introduced industry variation into our estimates of the PDV of depreciation allowances by letting

$$
z_{s t}=\left[\frac{I_{s t}^{E S}}{I_{s t}}\right] \times z_{t}^{E S}+\left[\frac{I_{s t}^{N R S}}{I_{s t}}\right] \times z_{t}^{N R S}
$$

where $I_{s t}=I_{s t}^{E S}+I_{s t}^{N R S}$ denotes business fixed investment in industry $s$, and where once again all the industry-specific investment series were interpolated from annual to monthly frequency using cubic splines. The resulting monthly PDV of depreciation allowances at the industry level were then averaged over the 12 relevant months of each firm's fiscal year and merged with the annual firm-level data.

allowances for business spending on E\&S in the form of 30 percent partial expensing; in 2003, this bonus depreciation was raised to 50 percent.

${ }^{25} \mathrm{As}$ in the case of depreciation rates, we used the logit and inverse logit transformations to ensure that the interpolated series remained in the $(0,1)$ range. 


\section{B Income and Balance Sheet Data}

This appendix describes the construction of the firm-specific variables used in our analysis. In variable definitions, $x_{n}$ denotes the Compustat data item $n$.

- Investment: Nominal gross investment in year $t\left(x_{30}\right)$ was deflated by the industryspecific price deflator for new investment $P_{s t}^{I}$.

- Capital Stock: The book value of net property, plant, and equipment at the end of year $t\left(x_{8}\right)$ was deflated by the industry-specific price deflator for capital stock $P_{s t}^{K}$.

- Sales: Net sales in year $t\left(x_{12}\right)$ were deflated by the industry-specific price deflator for gross output $P_{s t}^{Y}$.

- Operating Income: Operating income (or loss) in year $t\left(x_{13}\right)$ was deflated by the industry-specific price deflator for gross output $P_{s t}^{Y}$.

- Tobin's Q: The average Q was defined as the ratio of the sum of the market value of common shares outstanding and the book value of total liabilities at the end of year $t\left(x_{25} \times x_{199}\right)$ to the book value of total assets at the end of year $t\left(x_{6}\right)$.

The real investment rate $[I / K]_{j t}$ was then defined as the ratio of real investment expenditures in year $t$ relative to the real capital stock at the end of year $t-1$; sales to capital $[S / K]_{j t}$ and operating income to capital $[\Pi / K]_{j t}$ ratios were similarly scaled by the real capital stock at the end of year $t-1$. To ensure that our results were not influenced by a small number of extreme observations, we dropped from our panel all observations that failed to satisfy any of the following four criteria:

1. $0.01 \leq[I / K]_{j t} \leq 1.00$;

2. $0.00<[S / K]_{j t} \leq 25.0$;

3. $-0.50 \leq[\Pi / K]_{j t} \leq 3.00$;

4. $0.00<Q_{j t}^{A V G} \leq 40.0$.

To construct the industry-specific scaling constants $\phi_{s}$ and $\psi_{s}$ used to calculate our estimates of the marginal product of capital, we constructed a panel of all nonfarm, nonfinancial firms in Compustat during the 1987-2005 period and from which we eliminated all extreme observations using the same four selection criteria as above. Recall that the scaling constants $\phi_{s}$ and $\psi_{s}$ are intended to account for the fact that the sales-to-capital and operating-income-to-capital ratios vary substantially across industries, whereas in equilibrium, the return on capital should be the same across industries. To capture this intuition, we let

$$
\phi_{s}=\left(\frac{1}{M T} \sum_{j \in M} \sum_{t \in T_{j}} C_{j t}^{K}\right)\left(\frac{1}{N_{s} T} \sum_{j \in N_{s}} \sum_{t \in T_{j}}\left[\frac{S}{K}\right]_{j t}\right)^{-1},
$$

and

$$
\psi_{s}=\left(\frac{1}{M T} \sum_{j \in M} \sum_{t \in T_{j}} C_{j t}^{K}\right)\left(\frac{1}{N_{s} T} \sum_{j \in N_{s}} \sum_{t \in T_{j}}\left[\frac{\Pi}{K}\right]_{j t}\right)^{-1},
$$


where $M$ is the number of firms in our panel, $N_{s}$ is the number of nonfarm, nonfinancial Compustat firms in industry $s$, and $T=\sum_{j} T_{j}$ denotes the time-series dimension of each panel.

The first term in both expressions is simply the sample average - across firms and yearsof the user cost of capital, calculated using our panel of 898 firms over the 1987-2005 period. The second terms correspond to the sample averages of the sales-to-capital and operating-income-to-capital ratios for industry $s$, respectively, calculated using the panel of all nonfarm, nonfinancial firms in Compustat over the same period. Thus, the industryspecific scaling factors $\phi_{s}$ and $\psi_{s}$ are defined so that the sales-to-capital and operatingincome-to-capital ratios of different industries are, on average, equal to the average rate of return on capital - as measured by our estimate of the user cost-over the 1987-2005 period. 